\title{
DIE WAARNEMING VAN LUIDHEID AS BASIS VIR DIE METING VAN GERAAS- STEURING EN PRODUKTIWITEIT: 'N INTERNASIONALE ONDERSOEK
}

\author{
A.J. VAN WYK \\ DEPARTEMENT BEDRYFSIELKUNDE \\ UNIVERSITEIT VAN STELLENBOSCH
}

\section{SUMMARY}

\begin{abstract}
Human perception of loudness is considered the basis for noise measurement techniques. Due to the use of 18 different internationally accepted calculation methods which lead to much confusion, an International Round Robin project was organized for the evaluation of these methods under uniform conditions. The Stevens method proved to be the best overall simulation of human perception of loudness while the Zwicker and PNdB methods produced the best results at low and high intensity levels respectively. It was furthermore concluded that cultural differences between various participating groups had no significant effect on the perception of loudness. Research results obtained at national level can therefore be projected on international standards.
\end{abstract}

Gedurende 1946 is op 'n vergadering in Londen deur afgevaardigdes van 25 lande besluit om ' $n$ internasionale organisasie te stig met die doel om industriële standaarde internasionaal te koördineer (Internasionale Standaardisasie Organisasie, 1973). Amptelik het die Internasionale Standaardisasie Organisasie op 23 Februarie 1947 begin funksioneer en sedertdien uitgebrei tot 'n ledetal van 58 lande. Standaarde neergelê deur hierdie liggaam word egter reeds deur 73 lande toegepas. Die doel van die Internasionale Standaardisasie Organisasie is gemik op wêreldwye ooreenstemming ten opsigte van internasionale standaarde met die oog op uitbreiding in handel, verbetering in kwaliteit van produksie, toename in produktiwiteit en 'n verlaging van pryse. Hierdie liggaam beskerm dus die belange van vervaardigers, gebruikers, regeringsinstansies en wetenskaplikes deur eenvormige voorbereiding van internasionale standaarde.

Weens die toenemende druk van die internasionale openbare mening, is die Internasionale Standaardisasie Organisasie-beweging in die jongste tyd ook betrek by die neerlê van standaarde ten opsigte van omgewingsbesoedeling.

Geraasbesoedeling as menslike steuringsfaktor is reeds so 'n ernstige probleem dat die Internasionale Standaardisasie Organisasie elke twee jaar vergader om oplossings daarvoor te soek. Verskeie werkgroepe en studiegroepe is ook reeds gevorm om verskillende aspekte van 
geraasbesoedeling te ondersoek. Gedurende 'n internasionale kongres, gehou vanaf 6 tot 10 September 1971 in Weenen, Oostenryk, het die Suid-Afrikaanse afvaardiging die standpunt ingeneem dat 'n formule gevind moet word waardeur geraas op internasionale basis eenvormig gemeet kan word. Die rede hiervoor is dat verskillende lande op grond van interne navorsingsprojekte standaarde neerlê vir geraas veroorsaak deur byvoorbeeld vliegtuie, voertuie, treine, masjinerie, ensovoorts. Afhangende van watter meettegnieke gebruik word, kan daar dus verskillende standaarde bestaan tussen verskillende lande ten opsigte van soortgelyke geraasbronne.

Die implikasies van verskillende standaarde op invoere en uitvoere van produkte is duidelik. Indien geraasmetings deur byvoorbeeld Amerika op 'n ander grondslag deurgevoer word as in Suid-Afrika, beteken dit dat sekere Amerikaanse produkte nie na Suid-Afrika ingevoer kan word nie omdat die operasionele geraas daardeur veroorsaak, Suid-Afrikaanse standaarde oorskry. Suid-Afrika sou aan die ander kant byvoorbeeld nie sonder spesiale ontwerp geraasproduserende produkte na Frankryk kon uitvoer indien strenger standaarde ten opsigte van geraas daar geld as plaaslik nie.

Geraasmetings het voorts ook 'n polities-ekonomiese dimensie verkry wat navorsing in hierdie rigting uiters gevoelig raak. Aan die een kant is soveel kapitaal reeds bestee aan die ontwerp en gebruik van produkte wat geraas veroorsaak, dat sekere lande uiters versigtig is vir basiese navorsing wat moontlike ekonomiese verliese kan meebring. Aan die ander kant kan die volgende ekonomiese realiteite van geraasbesoedeling in terme van produktiwiteit en omgewingskoste nie ignoreer word nie:

\section{Produktiwiteit}

Verskeie navorsers het reeds aangetoon dat oormatige geraas 'n uitwerking het op die produktiwiteit van werknemers. Broadbent en Little (1960) bevind byvoorbeeld 'n afname in produktiwiteit by intensiteitspeile bo $90 \mathrm{~dB}$ (A), terwyl van Wyk (1970) 'n progressiewe daling in kwaliteit van prestasie onder geraastoestande identifiseer. Hierdie resultate bevestig die vermoede dat geraas 'n negatiewe invloed op die produktiwiteit van werknemers het. Afgesien hiervan vind Cameron, Robertson et.al. (1972) dat die gesondheid van werkers ook deur oormatige geraas beïnvloed word. As in ag geneem word dat die bestuur van organisasies aanspreeklik gehou word vir beserings en ander siektetoestande van werknemers, kan verwag word dat kompensasie-eise in die toekoms sal toeneem weens 'n voortdurende toename in geraasblootstelling van werknemers. 


\section{Omgewingskoste}

In die algemene sosiale omgewing kleef reeds 'n stigma aan gebiede met 'n hoë geraasfaktor. Relatiewe stil omgewings word as 'n luukse beskou waarvoor die mens bereid is om ' $n$ bepaalde prys te betaal. Walters (1975) bevind 'n gemiddelde jaarlikse depresiasie van $22,5 \%$ op huise in die V.S.A. bokant die $\$ 10000$ prysklas wat aan intensiewe geraas blootgestel word. Hoë inkomstegroepe neig om weg te beweeg van geraasbesoedelde woonbuurte, terwyl laer inkomstegroepe weens ekonomiese redes gedwing word om onder geraastoestande te bly. Walters toon voorts aan dat daar 'n bepaalde verband bestaan tussen die hoeveelheid geraasblootstelling en die persentuele effek op eiendomspryse. Gegewens soos hierdie het ook reeds aanleiding gegee tot kompensasie-eise. Gedurende 1970 is deur ' $n$ hofbevel bedrae van 800 dollar tot 6000 dollar uitbetaal aan 600 huiseienaars wat kon aantoon dat vliegtuiggeraas depresiasie van eiendomme meebring.

As 'n moontlike oplossing vir die vliegtuiggeraasprobleem, spekuleer Walters (op.cit.) dat vliegtuie relatief stiller gemaak kan word ten einde te voorkom dat huiseienaars in omgewings van lughawens onrealistiese skade ly. Spekulatief word die koste om die bestaande vliegtuie in die Verenigde State van Amerika aanvaarbaar stil te maak, beraam op ongeveer 2 biljoen dollar. Hierdie bedrag sluit egter nie die koste-implikasies van moontlike verkorte roetes en instandhouding in nie. Indien verder aanvaar word dat ongeveer 1 miljoen huisgesinne of ongeveer 4 miljoen mense in Amerika deur vloegtuiggeraas gesteur word, sou hierdie huiseienaars in terme van persentuele depresiasie van eiendom ongeveer 1,4 biljoen dollar tot hierdie bedrag kon bydra. So 'n uiteensetting is egter 'n oorvereenvoudiging van die probleem omdat vliegtuiggeraas internasionale implikasies het en dus wêreldwye ekonomiese implikasies.

Teen die agtergrond van genoemde ekonomiese implikasies en 'n steeds groeiende toename in geraas in die moderne omgewing, is dit duidelik dat in die toekoms deeglike aandag gegee sal moet word aan beplanning van geraasbronne en/of die geografiese ligging waarin oormatige geraas voorkom. 'n Voorvereiste vir hierdie benadering is egter dat eenvormigheid bereik moet word ten opsigte van basiese beginsels van meting van geraas. 


\section{PROBLEEMSTELLING}

Die menslike waarneming van luidheid is reeds deur verskeie navorsers gebruik as basis vir die ontwikkeling van 18 verskillende internasionale standaarde (Meij, 1971). Of die verskille tussen hierdie metodes te wyte is aan foutiewe beplanning van eksperimentele navorsing, is egter nog geen uitgemaakte saak nie. As gevolg van die lengte van tyd wat toetse in hierdie gebied in beslag neem, word afleidings van resultate van relatief klein monsters gemaak. Voorts is daar nog geen bewyse in die literatuur dat kulturele verskille geen invloed op navorsingsgegewens het nie.

Vir die oplossing van die huidige internasionale verwarring ten opsigte van 18 verskillende standaarde wat vir die meting van luidheid geld, is 'n sogenaamde Internasionale Round Robin navorsingsprojek onderneem sodat hierdie meetmetodes onder eenvormige toestande evalueer kon word. Meer bepaald is die aandag gefokus op die volgende doelstellings:

\section{DOELSTELLINGS VAN DIE ONDERSOEK}

\section{Algemene doelstelling}

Om agtien internasionaal gestandaardiseerde meeteenhede vir die waarneming van luidheid onder eenvormige toestande met mekaar te vergelyk.

\section{Spesifieke doelstellings}

- Om een enkele meetmetode te selekteer wat op wetenskaplike grondslag waarneming van luidheid die beste weerspieël.

- Om die invloed van kulturele verskille tussen volke op luidheidsnavorsing te bepaal.

- Om op wetenskaplike wyse 'n stel empiriese gegewens van luidheidsbepalings beskikbaar te stel wat in die toekoms deur ander navorsers gebruik sal kan word. 
Dit spreek vanself dat daar nie binne die beperkte ruimte van 'n verslag soos hierdie in volle besonderhede ingegaan kan word op die talle fasette van 'n eenvormige eksperimentele ontwerp wat in 12 verskillende lande toegepas is nie. Slegs die hoofprobleemareas sal dus kortliks bespreek word.

\section{Fasiliteite en meettoerusting}

Hoogs gespesialiseerde fasiliteite en duur meettoerusting word in luidheidsnavorsing gebruik. By die onderskeie deelnemende laboratoria sou dus bestaande fasiliteite en meet toerusting gebruik word wat onderling van mekaar verskil. Hierdie probleem is soos volg benader:

Eerstens is 'n dokument saamgestel waarin alle besonderhede aangevra is ten opsigte van laboratoriumuitleg en meettoerusting. Sodoende kon, ten spyte van lang afstande, 'n duidelike beeld bekom word van die gehalte van toerusting en laboratoriumuitleg wat in die ondersoek gebruik sou word. Tweedens is 'n reeks vereistes saamgestel waaraan alle laboratoria moes voldoen ten einde eenvormigheid in die toetsomgewing te bereik.

\section{Toetsklanke}

Elke deelnemende Laboratorium het 'n reeks van 16 toetsbande ontvang wat eenvormig deur die Suid-Afrikaanse Buro vir Standaarde voorberei is.

\section{Instruksies aan toetsafnemers}

Aangesien die meerderheid van toetsafnemers geen opleiding in die gedragswetenskappe het nie, is in besonder aandag gegee aan die samestelling van toetsinstruksies aan toetsafnemers ten einde onbewuste beïnvloeding van toetsresultate te voorkom.

\section{Instruksies aan toetslinge}

Verskeie faktore verdien pertinente aandag by die samestelling van toetsinstruksies aan toetslinge vir die doeleindes van die huidige ondersoek. Ter illustrasie word die volgende faktore toegelig: 


\section{Woordbetekenisse}

Die huidige ondersoek is toegepas in verskillende lande onder verskillende taalgroepe. Die woordkeuse by die samestelling van instruksies is dus 'n belangrike faktor wat kan bydra tot die voorkoming van waninterpretasies en gevolglike swak prestasie deur toetslinge. Toetsinstruksies aan toetslinge is saamgestel deur eenvoudige taalgebruik, sodat woorde met verskillende interpretasies vermy kon word.

Toetsafnemers het opdrag ontvang om die toetsinstruksies aan toetslinge in die moedertaal van die betrokke toetslinge te laat vertaal. Hierin skuil egter die gevaar dat die vertaalde weergawe sou verskil van die oorspronklike weergawe soos beskikbaar gestel aan alle toetsafnemers. Om hierdie probleem te oorkom, het toetsafnemers verder opdrag ontvang om die vertaalde weergawe van die instruksies deur ' $n$ ander onafhanklike vertaler in Engels terug te laat vertaal en hierdie weergawe in te dien saam met die toetsresultate. Hierdeur was dit moontlik om enige afwykings van die oorspronklike toetsinstruksies na te gaan en te kontroleer.

\section{Stemintonasie}

Met die doelstelling van ' $\mathrm{n}$ konstante voorafinstelling by toetslinge is vereis dat toetsafnemers nie die toetsinstruksies verbaal mag oordra aan toetslinge nie. Elke toetsling ontvang dus die geskrewe toetsinstruksies in sy eie moedertaal. Hierdeur word die effek van stemintonasie, wat sielkundige ingesteldheid mag projekteer, sowel as wisseling in gevoel van entoesiasme by toetsafnemers uitgeskakel.

\section{Die verstaan van toetsinstruksies deur toetslinge}

Dit is nodig dat toetslinge vooraf deur instruksies duidelikheid verkry van wat verwag word gedurende toetssessies aangesien wanbegrip nie in die loop van 'n toetssessie reggestel kan word nie. Ten einde vooraf te bepaal of toetslinge deeglik begryp wat die toetse inhou, is 'n kontrole-vraelys ontwerp wat baseer is op die inhoud van die toetsinstruksies aan toetslinge en deur toetslinge voltooi voor die aanvang van eksperimentele toetse.

\section{Houdingsvraelys aan toetslinge}

'n Houdingsvraelys wat deur toetslinge voltooi is na sy/haar laaste toetssessie is vir die volgende doeleindes aangewend: 


\section{Die kontrole van toetsafnemerinvloede}

Hierdie vraelys sluit sekere items in om te bepaal of die toetsafnemer nie ten spyte van alle voorsorgmaatreëls en instruksies nogtans 'n negatiewe invloed uitoefen op toetslinge gedurende die eksperimentele navorsing nie (kyk Tabel 1).

\section{Bepaling van die algemene houding van toetslinge teenoor die navorsingsprojek}

Verskeie skrywers erken dat die houding van toetslinge 'n invloed op toetsresultate het (Rosenberg, 1965), (Orne, 1962), (Stricker, 1967). Ten spyte van doeltreffende selektering van toetslinge en deeglike beplande instruksies, is dit in belang van wetenskaplike navorsing om die houding van toetslinge teenoor die navorsingsprojek na te gaan. Sodanige houdingsopname voorsien 'n rasionele kontrole en geldige rede tot eliminasie van resultate wat ver afwyk van ander (Sidowski,1966).

\section{TABEL 1}

\section{ITEMS VIR DIE KONTROLE VAN WAAMEMINGSINVLOEDE}

\begin{tabular}{|c|l|}
\hline Vraelys Item no. & \multicolumn{1}{|c|}{ Item } \\
\hline 2 & Mate van vermoeidheid \\
4 & Gemak gedurende toetssessies \\
8 & Mate van verveeldheid \\
9 & Onderskeidingsvermoë \\
10 & Houding t.o.v. terugvoering \\
12 & Aandag afgetrek \\
14 & Geforseerde deelname \\
15 & Spanning gedurende sessies \\
17 & Vrees vir swak prestasie \\
18 & Houding t.o. v. waarneming deur toetsafnemer \\
19 & Eerste vs. laaste toetssessie \\
20 & Gevoe1 van bedruktheid \\
\hline
\end{tabular}

Verder kan belangrike afleidings ook van die gemiddelde houdings van verskillende groepe toetslinge gemaak word. Indien beduidende verskille tussen laboratoria ten opsigte van toetsprestasies voorkom, sal 'n ontleding van toetslinghoudings moontlik kulturele verskille tussen groepe aantoon wat belangrike implikasies vir internasionale standaardisasie kan inhou. Beduidende verskille tussen die houdings van toetslinge in die verskillende laboratoria sou 'n aanduiding wees dat internasionale standaardisasie slegs kan plaasvind indien van internasionale monsters gebruik gemaak word in navorsingsprojekte. Onbeduidende verskille sou egter aantoon dat kulturele faktore waarskynlik nie 'n invloed uitoefen op luidheidsnavorsing nie en dat die Internasionale Standaardisasie Organisasie wel standaarde mag neerlê op grond 
van nasionale navorsingsprojekte. Die volgende items is in Tabel 2 saamgestel om die algemene houding van toetslinge teenoor die navorsingsprojek te meet:

\section{$\underline{\text { TABEL } 2}$}

\section{DIE HOUDING VAN TOETSLINGE TEENOOR NAVORSING}

\begin{tabular}{|c|l|}
\hline Vraelys Item No. & \multicolumn{1}{|c|}{ Item } \\
\hline 1 & Belangrikheid van navorsing \\
3 & Interessantheid van navorsing \\
5 & Algemene belangstelling in navorsing \\
6 & Eie oordeel van akkuraatheid \\
7 & Gewilligheid tot deelname in die toekans \\
11 & Beste gelewer \\
16 & Interessantheid van toetse \\
\hline
\end{tabular}

Vereistes ten opsigte van die seleksie van toetslinge

Ten einde ' $n$ verteenwoordigende monster te verkry, is die toetsafnemers van die onderskeie laboratoria versoek om 'n gelyke aantal manlike en vroulike toetslinge te selekteer. Die monster van proefpersone moes aan die volgende vereistes voldoen:

- Eerstens moes alle toetslinge oudiometries getoets word vir normale gehoor. Spesifiek is bepaal dat die gehoorverlies van toetslinge by frekwensies van $125 \mathrm{~Hz}$ en $250 \mathrm{~Hz}$ nie $15 \mathrm{~dB}$ sal oorskry nie en dat die gehoorverlies van toetslinge by frekwensies $500 \mathrm{~Hz}, 1000 \mathrm{~Hz}, 2000 \mathrm{~Hz}, 4000 \mathrm{~Hz}$ en $8000 \mathrm{~Hz}$ nie meer as $10 \mathrm{~dB}$ sal wees nie.

- Slegs toetslinge binne die ouderdomsgrens van 18 tot 25 jaar kon vir eksperimentele deelname aanvaar word. Die rede hiervoor is dat volgehoue deelname uitputtend kan wees en dat jong volwasse toetslinge ' $n$ besliste voordeel inhou vir die kwaliteit van toetsresultate. As algemene reël kan ook aanvaar word dat gehoorverlies minder ernstig voorkom tot ouderdom 26 jaar en dat hierdie vereiste die seleksie van toetslinge vir toetsafnemers aansienlik vergemaklik.

- Aangesien die aard van die eksperimentele opset 'n gevoel van isolasie by toetslinge kan ontwikkel, is pertinent aan toetsafnemers opdrag gegee om enige toetsling, wat volgens sy eie kommentaar, aan claustrofobiese neigings ly, uit te sluit. Om hierdie rede asook die verlangde positiewe houding van toetslinge, is deelnemers versoek om slegs van vrywilligers gebruik te maak. 
Die monster van gegewens

$\mathrm{Na}$ voltooiing van die eksperimentele ontwerp is 'n ope uitnodiging tot deelname aan alle lede van die Internasionale Standaardisasie Organisasie gerig. 'n Totaal van 23 laboratoria uit 12 verskillende lande soos in Tabel 3 uiteengesit, het hierdie uitnodiging aanvaar.

Ongelukkig moes sommige laboratoriums weens die hoë tegniese vereistes en ander weens politieke druk onttrek. Soos in Tabel 3 aangetoon, is 3 laboratoriums tans nog besig met die navorsing en word nie by die huidige ondersoek ingesluit nie. Die rede hiervoor is dat die Internasionale Standaardisasie Organisasie die bevindinge van die huidige ondersoek voor April 1976 verlang het.

\section{$\underline{\text { TABEL } 3}$}

Deelnemende Laboratoria

\begin{tabular}{|l|cc|}
\cline { 2 - 3 } \multicolumn{1}{c|}{} & \multicolumn{2}{c|}{ Aantal Laboratoriuns } \\
\hline België & Aanvanklik & Navorsing \\
\hline Duitsland & 1 & 1 \\
Engeland & 2 & 2 \\
Frankryk & 1 & 0 \\
Hongarye & 1 & $*$ \\
Japan & 1 & 1 \\
Oostenryk & 1 & 1 \\
Suid-Afrika & 1 & $*$ \\
Swede & 8 & 2 \\
Switserland & 1 & 0 \\
Tjeggoslowakye & 1 & $*$ \\
V.S.A. & 4 & 0 \\
\hline & 1 & 0 \\
\hline \multicolumn{1}{|c|}{12} & 23 & 7 \\
\hline
\end{tabular}

* Tans nog besig met eksperimentele navorsing.

Die gegewens van die 7 laboratoriums wat vir die huidige ondersoek ingesluit word, kan soos volg opgesom word: 


\section{Toetslinge}

- $\quad$ Die totale monster kom te staan op 218 toetslinge, bestaande uit 141 mans en 77 dames.

- Die gemiddelde ouderdom van die toetslinge is 22,57 jaar.

- Die gemiddelde gehoorverlies van die toetslinge word in Figuur 1 uiteengesit:

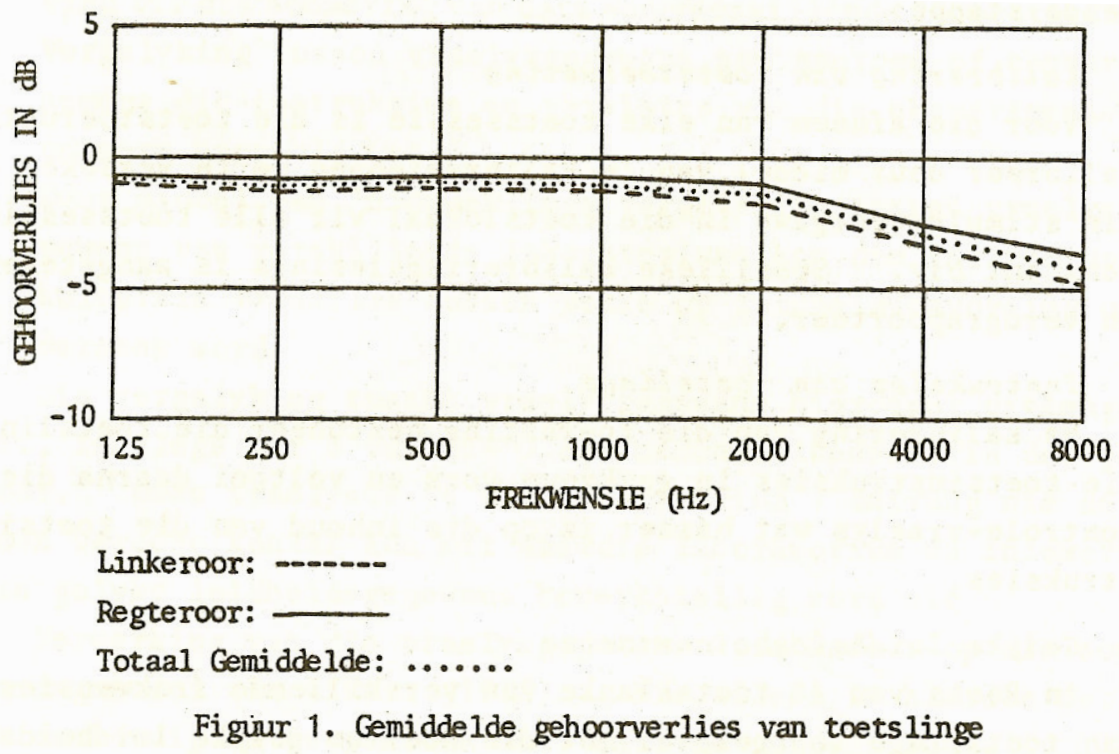

\section{Aantal toetse}

'n Totaal van 1434 toetse is voltooi. Elkeen van hierdie toetse bestaan uit 3 gelyke luidheidswaardes, sodat daar 43002 gelyke luidheidswaardes vir die ontleding van gegewens beskikbaar was.

\section{Die toetsprosedure}

As basiese uitgangspunt vir die huidige ondersoek is menslike gehoor as objektiewe meetinstrument beskou. Die vaste toetsprosedure is dus daarop gemik om die subjektiewe beïnvloedingsprosesse van toetsafnemers, toetsinstruksies en fisiese omgewingsfaktore by die luidheidsbeoordeling van klanke te vermy. Die toetsprosedure bestaan kortliks uit die volgende stappe: 


\section{Kalibrering van toetstoerusting}

Voor die afneem van elke toetssessie is die toetstoerusting kalibreer deur middel van 'n kalibrasieband om te verseker dat die stimulusweergawe in die toetslokaal vir alle toetssessies konstant bly. Spesifieke kalibreringslesings is aangeteken en terugrapporteer.

\section{Instruksies aan toetslinge}

Na kalibrering van die toerusting bestudeer die toetsling die toetsinstruksies in geskrewe vorm en voltooi daarna die kontrole-vraelys wat baseer is op die inhoud van die toetsinstruksies.

\section{Gelyke luidheidsbalanstoetse}

'n Reeks van 48 toetsklanke van verskillende frekwensies is aan toetslinge voorgespeel met die doel om gelyke luidheidswaardes met behulp van die metode van konstante stimulus te verkry. 'n Konstante verwysingstoon van $1000 \mathrm{~Hz}$ is in alle gevalle gebruik. Hierbenewens is die repertoire van toetsklanke ook aangebied in drie kategorieë van verwysingspeile naamlik $55 \mathrm{~dB}, 75 \mathrm{~dB}$ en $95 \mathrm{~dB}$.

\section{VERGELYKING VAN HOUDINGSVRAELYSGEGEWENS}

As eerste fase in die ontleding van gegewens is die houdingsvraelyste van die verskillende groepe toetslinge vergelyk. Sodanige vergelyking is belangrik geag om die volgende drie redes:

- $\quad$ In 'n internasionale luidheidsondersoek waarin toetsing van verskillende kultuurgroepe en verskillende tipes meettoerusting gebruik word, is dit belangrik om 'n wetenskaplike basis te vind vir die sommering van data van verskillende laboratoriums.

- Vergelyking tussen vraelysgegewens sou aantoon of toetsafnemers die instruksies en vereistes van die eksperimentele ontwerp nagevolg het.

- Deur middel van 'n onderlinge vergelyking tussen vraelysgegewens van verskillende laboratoriums kon die invloed van kulturele verskille tussen volke op luidheidsnavorsing ondersoek word.

Die vergelyking tussen vraelysgegewens hieronder uiteengesit, is slegs vir 6 van die 7 deelnemende laboratoria deurgevoer. Geen vraelyste is van laboratorium 7 ontvang nie en 
geen verdere kontak kon met hierdie laboratorium na inlewering van gelyke luidheidsgegewens bewerkstellig word nie.

Verwerking van die vraelysgegewens word baseer op die sommeringsmodel van Likert (1932). Nie alleen is hierdie metode eenvoudig om te gebruik nie, maar is volgens Nunnally (1970) ook 'n hoogs betroubare metode wat gebruik kan word vir die bepaling van 'n wye verskeidenheid van houdings. Deur die sommeringsmodel word toepaslike items van 'n vraelys bymekaar getel vir die bepaling van totale en gemiddelde tellings. Omskakeling van die tellings van negatiewe itemstellings word toegelaat sodat alle skaalwaardes in dieselfde rigting interpreteer kan word.

Die houdings van toetslinge teenoor die navorsingsprojek

Items 1, 3, 5, 6, 7, 11 en 16 (kyk Tabel 2) van die houdingsvraelys aan toetslinge is ontwerp vir die bepaling van die houding van toetslinge teenoor die navorsingsprojek. Die gemiddelde houding van toetslinge op hierdie items, soos uitgedruk op 'n 9-punt skaal, word per individuele laboratorium in Tabel 4 uiteengesit:

\section{TABEL 4}

\section{GEMIDDELDE HOUDING VAN TOETLINGE TEENOOR DIE NAVORSINGSPROJEK}

\begin{tabular}{|l|c|c|c|c|c|c|}
\hline Laboratorium & 1 & 2 & 3 & 4 & 5 & 6 \\
\hline Aantal vraelyste & 26 & 25 & 29 & 35 & 16 & 24 \\
\hline Gemiddelde telling & 7,35 & 6,18 & 7,49 & 7,28 & 7,49 & 7,19 \\
\hline
\end{tabular}

Uit Tabel 4 blyk dat gemiddeld geen negatiewe houding teenoor die navorsingsprojek deur enige laboratorium rapporteer word nie. Alhoewel alle gemiddelde tellings bokant 'n 5waarde op die 9-punt skaal aangedui word, is dit nodig om te bepaal of daar 'n beduidende verskil tussen die positiewe houdings van toetslinge bestaan. 'n Variansieontleding van bostaande gegewens word in Tabel 5 aangetoon: 
$\underline{\text { TABEL } 5}$

VARIANSIEONTLEDING VAN DIE GEMIDDELDE HOUDING VAN TOETSLINGE TEENOOR DIE NAVORSINGSPROJEK

\begin{tabular}{|l|r|r|c|c|}
\hline Soort variansie & $\begin{array}{c}\text { Som van } \\
\text { kwadrate }\end{array}$ & G.V. & $\begin{array}{c}\text { Skatting van } \\
\text { Groepvariansie }\end{array}$ & F \\
\hline Tussen groepe & 30,5134 & 5 & 6,1027 & \\
Binne groepe & 148,4269 & 149 & 0,9962 & $6,1263^{*}$ \\
\hline$* \mathrm{p}<, 01$
\end{tabular}

Uit Tabel 5 blyk dat daar beduidende verskille tussen die 6 groepe toetslinge se gemiddelde houdings teenoor die navorsingsprojek bestaan ( $\mathrm{p}, 01)$. Hierdie verskille word verder ontleed volgens Scheffé (1959) se "a posteriori" metode van variansieontleding en in Tabel 6 uiteengesit:

\section{TABEL 6}

Verskille tussen Laboratoriums ten opsigte van Houding teenoor die Navorsingsprojek

\begin{tabular}{|c|c|c|c|c|c|c|}
\cline { 2 - 7 } \multicolumn{1}{c|}{} & \multicolumn{5}{c|}{ F-waardes } \\
\hline $\begin{array}{c}\text { Labora- } \\
\text { torium }\end{array}$ & 1 & 2 & 3 & 4 & 5 & 6 \\
\hline 1 & & & & & & \\
2 & $17,56^{*}$ & & & & & \\
3 & 0,27 & $23,23^{*}$ & & & & \\
4 & 0,08 & $17,72^{*}$ & 0,72 & & & \\
5 & 0,19 & $16,97^{*}$ & 0,00 & 0,50 & & \\
6 & 0,32 & $12,60^{* *}$ & 1,19 & 0,12 & 0,88 & \\
\hline
\end{tabular}

${ }^{*} \mathrm{p}<, 05$

$* * \mathrm{p}<, 01$

Die berekening van die F-waardes in bostaande tabel is bepaal deur middel van die formule:

$$
F=t^{2}=\frac{\left(\bar{X}_{1}-\bar{X}_{2}\right)^{2}}{\frac{S_{b}^{2}}{n_{1}}+\frac{S_{b}^{2}}{n_{1}}}
$$

waar $\mathrm{S}_{\mathrm{b}}^{2}=$ skatting van groepvariansie binne groepe. 
Volgens die F-tabelle is F,05 = 2,27 en F,01 = 3,14. Die kritiese beduidendheidswaarde $F^{1}$ volgens die Scheffé (1959) metode word bepaal deur die formule: $F^{1}=(k-1) F$ waar $\mathrm{k}=$ aantal groepe

$\therefore \mathrm{F}^{1}, 05=11,35$

en $\mathrm{F}^{1}, 01=15,70$

Uit Tabel 6 blyk dat die gemiddelde houding van toetslinge in laboratorium 2 beduidend verskil van laboratoriums $1,3,4$ en $5(\mathrm{p}<, 05)$ en ook beduidend verskil van laboratorium $6(\mathrm{p}<, 01)$. 'n Moontlike verklaring vir hierdie beduidend minder positiewe houding van toetslinge in laboratorium 2 is dat toetslinge finansieel vergoed is vir deelname aan die ondersoek. Laboratorium 2 kon geen toetslinge op 'n vrywillige grondslag bekom nie, en moes noodgedwonge van vergoeding by rekrutering van toetslinge gebruik maak. Uit Tabel 6 blyk verder dat daar geen beduidende verskille tussen laboratorium 1, 3, 4, 5 en 6 voorkom ten opsigte van die houding van toetslinge teenoor die navorsingsprojek nie.

\section{Die kontrole of toetsafnemers}

Die mate waartoe toetsafnemers die vereistes en instruksies van die ondersoek nagevolg het, word kontroleer deur ' $\mathrm{n}$ aantal items in die houdingsvraelys aan toetslinge en in die volgende kategorieë verdeel:

- Geforseerde deelname (item 14 van die vraelys).

- $\quad$ Spanning en vermoeidheid (items 2, 4, 8, 9, 15 en 17 van die vraelys).

- Houding teenoor waarneming deur toetsafnemers (items 10 en 18 van die vraelys).

- $\quad$ Aandag afgetrek deur buitefaktore (item 12 van die vraelys).

- Konstantheid in oordeel (item 19 van die vraelys).

- $\quad$ Claustrofobiese neigings (item 20 van die vraelys).

Die afsonderlike ontleding van hierdie kategorieë word hieronder uiteengesit:

\section{Geforseerde deelname}

Die mate waartoe druk uitgeoefen is op toetslinge om deel te neem aan die eksperimentele navorsing word in Tabel 7 uiteengesit. 
$\underline{\text { TABEL } 7}$

GEFORSEERDE DEELNAME

\begin{tabular}{|l|c|c|c|c|c|c|}
\hline Laboratorium & 1 & 2 & 3 & 4 & 5 & 6 \\
\hline Aantal toetslinge & 26 & 25 & 29 & 35 & 16 & 24 \\
\hline Gemiddelde telling & 1,69 & 1,72 & 1,41 & 2,26 & 1,50 & 1,04 \\
\hline
\end{tabular}

Uit Tabel 7 blyk dat geen laboratorium 'n sterk drukuitoefening op 'n 9-punt skaal rapporteer nie. ' $n$ Verdere verwerking van hierdie gegewens word in Tabel 8 uiteengesit:

$\underline{\text { TABEL } 8}$

\section{VARIANSIEONTLEDING VAN GEGEWENS OOR GEFORSEERDE DEELNAME TUSSEN VERSKILLENDE GROEPE TOETSLINGE}

\begin{tabular}{|c|c|c|c|c|}
\hline Soort variansie & $\begin{array}{c}\text { Som van } \\
\text { kwadrate }\end{array}$ & G.V. & $\begin{array}{c}\text { Skatting van } \\
\text { Groepvariansie }\end{array}$ & F \\
\hline Tussen groepe & 23,9301 & 5 & 4,7860 & \multirow{2}{*}{$2,3990^{*}$} \\
\cline { 1 - 4 } $\begin{array}{c}\text { Binne groepe } \\
{ }^{*} \mathrm{p}<, 05\end{array}$ & 297,2570 & 149 & 1,9950 & \\
\hline
\end{tabular}

Uit Tabel 8 blyk dat beduidende verskille tussen laboratoria ten opsigte van geforseerde deelname $(\mathrm{p}<, 05)$ voorkom. Alhoewel $\mathrm{F}=2,3990$ baie naby is aan die kritiese $\mathrm{F}, 05=2,27$ is dit nogtans wenslik om hierdie geringe beduidenheid verder te ontleed volgens die Scheffé (1959) metode van variansieontleding. Hierdie ontleding word in Tabel 9 uiteengesit:

$\underline{\text { TABEL } 9}$

BEDUIDENDHEID VAN VERSKILLE TUSSEN LABORATORIUMS TEN OPSIGTE VAN GEFORSEERDE DEELNAME

\begin{tabular}{|c|c|c|c|c|c|c|}
\cline { 2 - 7 } \multicolumn{1}{c|}{} & \multicolumn{6}{|c|}{ F-waardes* } \\
\hline Laboratorium & 1 & 2 & 3 & 4 & 5 & 6 \\
\hline 1 & & & & & & \\
2 & 0,01 & & & & & \\
3 & 0,53 & 0,63 & & & & \\
4 & 2,38 & 2,12 & 5,65 & & & \\
5 & 0,81 & 0,24 & 0,04 & 3,15 & & \\
6 & 2,65 & 2,82 & 0,91 & 10,53 & 1,01 & \\
\hline
\end{tabular}

* Almal onbeduidend 
Die kritiese waarde van $\mathrm{F}^{1}, 05=11,35$. Aangesien geen $\mathrm{F}$-waarde in Tabel 9 hierdie kritiese waarde oorskry nie, toon hierdie fyner ontleding van die gegewens dat daar geen beduidende verskil tussen laboratoriums voorkom ten opsigte van geforseerde deelname nie.

\section{Spanning en vermoeidheid}

Die mate van spanning en vermoeidheid deur toetslinge ondervind tydens toetssessies, word in Tabel 10 uiteengesit.

Uit Tabe1 10 blyk dat toetslinge oor die algemeen op die 9-punt skaal rapporteer dat hulle nie 'n hoë mate van spanning en vermoeidheid ondervind gedurende toetssessies nie.

$\underline{\text { TABEL } 10}$

SPANNING EN VERMOEIDHEID

\begin{tabular}{|l|c|c|c|c|c|c|}
\hline Laboratoriun & 1 & 2 & 3 & 4 & 5 & 6 \\
\hline Aantal toetslinge & 26 & 25 & 29 & 35 & 16 & 24 \\
\hline Gemiddelde telling & 3,36 & 3,95 & 3,50 & 3,86 & 3,70 & 3,52 \\
\hline
\end{tabular}

Hierdie gegewens word verder ontleed in Tabel 11 om te bepaal of daar beduidende verskille bestaan tussen laboratoriums ten opsigte van spanning en vermoeidheid.

\section{$\underline{\text { TABEL } 11}$}

\section{VARIANSIEONTLEDING VAN GEGEWENS TEN OPSIGTE VAN SPANNING EN} VERMOEIDHEID ONDERVIND GEDURENDE TOETSSESSIES

\begin{tabular}{|l|c|c|c|c|}
\hline Soort variansie & $\begin{array}{c}\text { Som van } \\
\text { kwadrate }\end{array}$ & G.V. & $\begin{array}{c}\text { Skatting van } \\
\text { Groepvariansie }\end{array}$ & F \\
\hline Tussen groepe & 7,1934 & 5 & 1,4387 & \multirow{2}{*}{1,0944} \\
\hline Binne groepe & 195,8728 & 149 & 1,3146 & \\
\hline
\end{tabular}

Uit Tabel 11 blyk dat daar geen beduidende verskil in spanning en vermoeidheid tussen laboratoriums voorkom nie.

\section{Houding teenoor waarneming deur toetsafnemers}

Die ontleding van gegewens ten opsigte van hierdie faktor word slegs gedoen vir laboratoriums 1, 2, 3, 5 en 6. Laboratorium 4 kon vanuit die aard van die laboratoriumuitleg 
die toetslinge nie waarneem nie en die items ten opsigte van waarneming is dus nie op die vraelyste voltooi nie. Die gemiddelde houding teenoor waarneming vir die ander laboratoriums word in Tabel 12 uiteengesit:

$\underline{\text { TABEL } 12}$

HOUDING TEENOOR WAARNEMING DEUR TOETSAFNEMERS

\begin{tabular}{|l|c|c|c|c|c|}
\hline Laboratoriun & 1 & 2 & 3 & 5 & 6 \\
\hline Aantal toetslinge & 26 & 25 & 29 & 16 & 24 \\
\hline Gemiddelde telling & 2,94 & 2,84 & 4,29 & 3,88 & 2,69 \\
\hline
\end{tabular}

Uit Tabel 12 blyk dat toetslinge nie oormatig beïnvloed is deur die waarneming van toetsafnemers nie. ' $n$ Variansieontleding van hierdie gegewens word in Tabel 13 uiteengesit om te bepaal of beduidende verskille tussen groepe ten opsigte van die houding teenoor waarneming voorkom.

\section{TABEL 13}

\section{VARIANSIEONTLEDING VAN GEGEWENS TEN OPSIGTE VAN DIE HOUDING VAN TOETSLINGE TEENOOR WAARNEMING DEUR TOETSAFNEMERS}

\begin{tabular}{|l|c|c|c|c|}
\hline Soort variansie & $\begin{array}{c}\text { Som van } \\
\text { kwadrate }\end{array}$ & G.V. & $\begin{array}{c}\text { Skatting van } \\
\text { Groepvariansie }\end{array}$ & F \\
\hline Tussen groepe & 51,4596 & 4 & 12,8649 & \multirow{2}{*}{$6,1150^{*}$} \\
\hline Binne groepe & 241,9383 & 115 & 2,1038 & \\
\hline
\end{tabular}

Uit Tabel 13 blyk dat beduidende verskille tussen die houdings van die onderskeie groepe toetslinge teenoor die waarneming deur toetsafnemers voorkom. 'n Verdere ontleding van hierdie gegewens word volgens die Scheffé (1959) metode bepaal en in Tabel 14 uiteengesit: 
$\underline{\text { TABEL } 14}$

\section{BEDUIDENDHEID VAN VERSKILLE TUSSEN LABORATORIUNS TEN OPSIGTE VAN DIE HOUDING TEENOOR WAARNEMING DEUR TOETSAFNEMERS}

\begin{tabular}{|c|c|c|c|c|c|}
\hline Laboratorium & 1 & 2 & 3 & 5 & 6 \\
\hline 1 & & & & & \\
\hline 2 & 0,06 & & & & \\
\hline 3 & $11,90 *$ & $13,40^{* *}$ & & & \\
\hline 4 & 4,20 & 4,97 & 0,85 & & \\
\hline 6 & 0,38 & 0,14 & $16,08^{* *}$ & 6,45 & \\
\hline
\end{tabular}

Die kritiese waarde van $\mathrm{F}^{1}, 05=10,76$ en $\mathrm{F}^{1}, 01=12,18$. Uit Tabel 14 blyk dat 'n beduidende verskil voorkom ten opsigte van hierdie gegewens tussen laboratorium 1 en 3 $(\mathrm{p}<, 05)$ en dat beduidende verskille ook voorkom tussen laboratoriums 2 en 3 sowel as tussen laboratoriums 3 en $6(\mathrm{p}<, 01)$. Hierdie resultate toon dat die toetslinge in laboratorium 3 beduidend meer negatief ingestel is teenoor waarneming deur toetsafnemers as alle ander laboratoriums behalwe laboratorium 5. In die kommentaar van toetslinge in laboratorium 3 op die vraelys word aangedui dat min of geen terugvoering van die toetsafnemer ontvang is nie. Die resultate in Tabel 14 dui dus daarop dat die mate van ongemak veroorsaak deur waarneming van toetslinge in luidheidsnavorsing, verlig word deur terugvoering of kennis van resultate.

\section{Aandag afgetrek deur buitefaktore}

Die gemiddelde reaksie van toetslinge teenoor die invloed van buitefaktore op konsentrasievermoë gedurende eksperimentele toetssessies word in Tabel 15 uiteengesit: 
$\underline{\text { TABEL } 15}$

AANDAG AFGETREK DEUR BUITEFAKTORE

\begin{tabular}{|l|c|c|c|c|c|c|}
\hline Laboratoriun & 1 & 2 & 3 & 4 & 5 & 6 \\
\hline Aantal toetslinge & 26 & 25 & 29 & 35 & 16 & 24 \\
\hline Gemiddelde telling & 2,35 & 2,68 & 1,79 & 3,00 & 2,63 & 2,42 \\
\hline
\end{tabular}

Uit bostaande gegewens blyk dat toetslinge oor die algemeen min gesteur is deur buitefaktore gedurende eksperimentele toetssessies, soos aangedui op 'n 9-punt skaal. 'n Verdere ontleding van hierdie gegewens word in Tabel 16 aangedui:

$\underline{\text { TABEL } 16}$

VARIANSIEONTLEDING VAN GEGEWENS OOR AANDAG AFGETREK GEDURENDE EKSPERIMENTELE TOETSSESSIES

\begin{tabular}{|l|c|c|c|c|}
\hline \multicolumn{1}{|c|}{ Soort variansie } & $\begin{array}{c}\text { Som van } \\
\text { kwadrate }\end{array}$ & G.V. & $\begin{array}{c}\text { Skatting van } \\
\text { Groepvariansie }\end{array}$ & F \\
\hline Tussen groepe & 25,0431 & 5 & 5,0086 & \multirow{2}{*}{$1,3430^{*}$} \\
\hline Binne groepe & 555,665 & 149 & 3,7293 & \\
\hline
\end{tabular}

Uit Tabel 16 blyk dat daar by geen laboratorium 'n beduidende groter bron van eksterne steuring voorkom as by ander laboratoriums nie.

\section{Konstantheid in oordeel}

Hierdie item is toegevoeg tot die vraelys om die toetsling se eie evaluering van prestasie gedurende sy eerste versus sy laaste toetsessie te bepaal. In hierdie geval is gebruik gemaak van 'n 5-kategorie verbale beoordelingskaal. Die gemiddeide reaksies van toetslinge in die onderskeie laboratoriums word in Tabel 17 uiteengesit: 
$\underline{\text { TABEL } 17}$

KONSTANTHEID IN OORDEEL VAN EERSTE VS. LAASTE TOETSSESSIE

\begin{tabular}{|c|c|c|c|c|c|c|}
\hline Laboratorium & 1 & 2 & 3 & 4 & 5 & 6 \\
\hline $\begin{array}{c}\text { Gemiddelde } \\
\text { reaksie }\end{array}$ & dieselfde & dieselfde & dieselfde & dieselfde & $\begin{array}{c}\text { dieselfde/ } \\
\text { beter }\end{array}$ & dieselfde \\
\hline
\end{tabular}

Dieselfde gemiddelde reaksie ten opsigte van hierdie item kom by alle laboratoriums voor, behalwe by laboratorium 5 waar 'n gemiddelde reaksie van dieselfde/beter reaksie verkry word.

\section{Gevoel van bedruktheid}

Hierdie item is toegevoeg tot die vraelys om te bepaal of toetsafnemers voorsorg getref het dat geen toetsling met claustrofobiese neigings aanvaar word vir eksperimentele navorsing nie. Aangesien geen toetsling in enige laboratorium 'n oormatige gevoel van bedruktheid aandui op die vraelys nie, kon aanvaar word dat toetsafnemers wel die instruksies ten opsigte van hierdie neiging gevolg het en dat geen persoon wat volgens sy eie kommentaar aan claustrofobiese neigings ly, vir eksperimentele deelname aanvaar word nie.

Uit die voorafgaande ontleding van die kontrole op toetsafnemers blyk dat geen beduidende verskil tussen groepe toetslinge ten opsigte van enige van die subgroeperings van kontrolemeganismes voorkom nie, behalwe in die geval van laboratorium 3 waar 'n beduidende negatiewe houding ten opsigte van waarneming deur toetsafnemers aangedui is.

Vir die doeleindes van die huidige projek wat 'n sommering van die gegewens van verskillende laboratoria beoog, is hierdie bevindinge belangrik. Kontrole-items in die houdingsvraelys aan toetslinge vorm 'n onafhanklike bron van inligting wat oor die algemeen aantoon dat toetsafnemers die instruksies en vereistes van die huidige ondersoek noukeurig gevolg het.

Alhoewel die invloed van die toetsafnemer op eksperimentele navorsing nie elimineer kan word nie, kan aanvaar word dat hierdie invloed gelykmatig verspreid voorkom oor die totale "Round Robin" projek en nie beduidende verskille in gelyke luidheidsresultate tussen laboratoria tot gevolg het nie. 


\section{ONTLEDING VAN GELYKE LUIDHEIDSRESULTATE}

\section{Tegniese Laboratoriumkorreksies}

Daar is vermeld dat in 'n internasionale ondersoek oor luidheid, waarby verskillende laboratoriums ingeskakel word, dit nie moontlik is om absolute eenvormigheid in meettoerusting te verkry nie. Alhoewel elke laboratorium moes voldoen aan streng vereistes, kan nie sondermeer aanvaar word dat daar geen verskille tussen laboratoriumgegewens bestaan ten opsigte van die onafhanklike veranderlikes wat in die metode van ondersoek voorkom nie.

Ten einde sodanige verskille tussen laboratoriums te kontroleer, is vereis dat elke toetsafnemer 'n tertsband of oktaafbandanalise van die toetslokaal uitvoer ten opsigte van die volgende middelfrekwensies: $50 \mathrm{~Hz}, 63 \mathrm{~Hz}, 80 \mathrm{~Hz}, 100 \mathrm{~Hz}, 125 \mathrm{~Hz}, 160 \mathrm{~Hz}, 200 \mathrm{~Hz}, 250 \mathrm{~Hz}$, $315 \mathrm{~Hz}, 400 \mathrm{~Hz}, 500 \mathrm{~Hz}, 630 \mathrm{~Hz}, 800 \mathrm{~Hz}, 1000 \mathrm{~Hz}, 1250 \mathrm{~Hz}, 1600$ Hz, 2000 Hz, 2500 Hz, $3150 \mathrm{~Hz}, 4000 \mathrm{~Hz}, 5000 \mathrm{~Hz}, 6300 \mathrm{~Hz}$ en $8000 \mathrm{~Hz}$.

'n Totaal van 23 middelfrekwensies wat die hele spektrumomvang van die ondersoek dek, is dus deur toetsafnemers uitgevoer. Enige afwykings vanaf 'n plat akoestiese respons word in die verwerking van gelyke luidheidsgegewens as tegniese laboratoriumkorreksies aangebring. Alhoewel wetenskaplik korrek, plaas hierdie korregering van data 'n beperking op die sommering van gegewens oor alle laboratoriums.

Die voorkoms van 'n tegniese laboratoriumkorreksie beteken prakties dat die intensiteit van 'n vergelykingsklank van laboratorium tot laboratorium nie presies dieselfde is nie. Gevolglik is dit nie moontlik om alle gelyke luidheidsresultate saam te groepeer indien laboratoriumkorreksies beduidende verskille in resultate veroorsaak nie.

Vir hierdie doel is die beduidendheid van verskille tussen resultate met en sonder laboratoriumkorreksies vir elkeen van die individuele laboratoria bereken om die invloed van tegniese laboratoriumkorreksies op toetsresultate te bepaal. 'n Afsonderlike ontleding vir toetsresultate op elk van die $55 \mathrm{~dB}, 75 \mathrm{~dB}$ en $95 \mathrm{~dB}$ verwysingspeile is uitgevoer en geen enkele beduidende verskil is ten opsigte van enige toetssein gevind nie. Hieruit kan afgelei word dat die toetsafnemers die tegniese vereistes van die projek streng nagevolg het en dat die tegniese verskille wat daar tussen laboratoria bestaan, so gering is dat dit nie 'n beperking plaas op die sommering van gegewens nie. 
In die geval van laboratorium 1 is egter 'n konstante fout opgespoor ten opsigte van die toetsprosedure wat nie reggestel kon word nie en hierdie laboratorium moes gevolglik uit die ondersoek elimineer word.

\section{Beduidendheid van verskille tussen gelyke luidheidswaardes}

As finale toets vir die sommering van gegewens is 'n vergelyking gedoen tussen die gelyke luidheidswaardes van die verskillende laboratoriums voordat enige laboratoriumkorreksie aangebring is. Hierdie toets is spesifiek gedoen om te bepaal of die gegewens van laboratorium 7 ingeskakel kan word by die verwerking van gegewens. Weer eens is die vergelyking gedoen vir elkeen van die afsonderlike verwysingspeile van $55 \mathrm{~dB}, 75 \mathrm{~dB}$ en $95 \mathrm{~dB}$ respektiewelik en word in Tabelle 18 tot 25 uiteengesit:

\section{$\underline{\text { TABEL } 18}$}

GEMIDDELDE GELYKE LUIDHEIDSWAARDES VAN TOETSKLANKE OP DIE 55 DB VERWYSINGSPEIL

\begin{tabular}{|l|c|c|c|c|c|c|}
\hline Laboratorium & 2 & 3 & 4 & 5 & 6 & 7 \\
\hline Aantal toetsklanke & 9 & 9 & 9 & 9 & 9 & 9 \\
\hline Gemiddelde waarde & 39,99 & 48,12 & 46,12 & 50,67 & 46,11 & 48,87 \\
\hline
\end{tabular}

Die gegewens in Tabel 18 word verder ontleed in Tabel 19 en toon dat beduidende verskille voorkom tussen die gelyke luidheidswaardes van verskillende laboratoriums op die $55 \mathrm{~dB}$ verwysingspeil $(\mathrm{p}<, 01)$.

\section{TABEL 19}

VARIANSIEANTLEDING VAN GELYKE LUIDHEIDSWAARDES OP DIE 55 DB VERWYSINGSPEIL

\begin{tabular}{|l|c|c|c|c|}
\hline \multicolumn{1}{|c|}{ Soort variansie } & $\begin{array}{c}\text { Som van } \\
\text { kwadrate }\end{array}$ & G.V. & $\begin{array}{c}\text { Skatting van } \\
\text { Groepvariansie }\end{array}$ & F \\
\hline Tussen groepe & 612,1163 & 5 & 122,4233 & $6,0548^{*}$ \\
\hline Binne groepe & 970,5296 & 48 & 20,2194 & \\
\hline$* \mathrm{p}<, 01$ &
\end{tabular}

'n Verdere ontleding van hierdie gegewens word volgens die Scheffé (1959) metode gedoen en in Tabel 20 uiteengesit: 
$\underline{\text { TABEL } 20}$

VERSKILLE TUSSEN GELYKE LUIDHEIDSWAARDES OP DIE 55 DB VERWYSINGSPEIL

\begin{tabular}{|c|c|c|c|c|c|c|}
\cline { 2 - 7 } \multicolumn{1}{c|}{} & \multicolumn{6}{c|}{ F-waardes } \\
\hline Laboratorium & 2 & 3 & 4 & 5 & 6 & 7 \\
\hline 2 & & & & & & \\
3 & $14,73 *$ & & & & & \\
4 & 9,07 & 0,68 & & & & \\
5 & $25,42^{* *}$ & 1,45 & 4,12 & & & \\
6 & 8,35 & 0,90 & 0,02 & 4,63 & & \\
7 & $17,54 *$ & 0,12 & 1,39 & 0,73 & 1,69 & \\
$* \mathrm{p}<05$ & \multicolumn{7}{|l}{} & \\
$* * \mathrm{p}<, 01$ &
\end{tabular}

Die kritiese waardes van $\mathrm{F}^{1}, 05=12,05$ en $\mathrm{F}^{1}, 01=17,10$. Uit Tabel 20 blyk dat die gegewens van laboratorium 2 beduidend verskil van laboratorium $3(\mathrm{p}<, 05)$ en ook beduidend verski1 van laboratoriums 5 en $7(\mathrm{p}<, 01)$. Geen beduidende verskille kom egter voor tussen laboratoriums 3, 4, 5, 6 en 7 ten opsigte van gelyke luidheidswaardes op die $55 \mathrm{~dB}$ verwysingspeil nie.

$\underline{\text { TABEL } 21}$

GEMIDDELDE GELYKE LUIDHEIDSWAARDES VAN TOETSKLANKE OP DIE 75 DB VERWYSINGSPEIL

\begin{tabular}{|l|c|c|c|c|c|c|}
\hline Laboratorium & 2 & 3 & 4 & 5 & 6 & 7 \\
\hline Aantal toetsklanke & 30 & 30 & 30 & 30 & 30 & 30 \\
\hline Gemiddelde waarde & 59,65 & 65,65 & 69,97 & 68,02 & 65,53 & 65,86 \\
\hline
\end{tabular}

Die gegewens in Tabel 21 word verder ontleed in Tabe1 22 om te bepaal of daar beduidende verskille tussen laboratoriums voorkom ten opsigte van gelyke luidheidswaardes op die $75 \mathrm{~dB}$ verwysingspeil. 
$\underline{\text { TABEL } 22}$

VARIANSIEONTLEDING VAN GELYKE LUIDHEIDSWAARDES OP DIE 75 DB VERWYSINGSPEIL

\begin{tabular}{|l|c|c|c|c|}
\hline Soort variansie & $\begin{array}{c}\text { Som van } \\
\text { kwadrate }\end{array}$ & G.V. & $\begin{array}{c}\text { Skatting van } \\
\text { Groepvariansie }\end{array}$ & F \\
\hline Tussen groepe & 1403,8582 & 5 & 280,7716 & \multirow{2}{*}{$13,4026^{*}$} \\
\hline Binne groepe & 3645,1270 & 174 & 20,9490 & \\
\hline$* \mathrm{p}<, 01$ &
\end{tabular}

Uit Tabe1 22 blyk dat daar beduidende verskille tussen 1aboratoriums bestaan ten opsigte van gelyke luidheidswaardes wat teen die $75 \mathrm{~dB}$ verwysingspeil gevind is $(\mathrm{p}<, 01)$. Hierdie beduidende verskille word verder ontleed deur die Scheffé (1959) metode en in Tabel 23 uiteengesit:

$\underline{\text { TABEL } 23}$ VERSKILLE TUSSEN GELYKE LUIDHEIDSWAARDES OP DIE 75 DB
VERWYSINGSPEIL

\begin{tabular}{|c|c|c|c|c|c|c|}
\cline { 2 - 7 } \multicolumn{1}{c|}{} & \multicolumn{5}{c|}{ F-waarde } \\
\hline Laboratorium & 2 & 3 & 4 & 5 & 6 & 7 \\
\hline 2 & & & & & & \\
3 & $25,77^{*}$ & & & & & \\
4 & $49,53^{*}$ & 3,85 & & & & \\
5 & $50,15 *$ & 4,02 & 0,00 & & & \\
6 & $24,78^{*}$ & 0,01 & 4,24 & 4,43 & & \\
7 & $27,64^{*}$ & 0,03 & 3,17 & 3,33 & 0,08 & \\
\hline
\end{tabular}

Die kritiese waarde van $\mathrm{F}^{1}, 01=15,70$. Uit Tabel 23 blyk dat die gegewens van laboratorium 2 beduidend verskil van die gegewens van laboratorium 3, 4, 5, 6 en 7 ( $\mathrm{p}<, 01)$. Geen beduidende verskille kom egter voor tussen die ander laboratoriums ten opsigte van gelyke luidheidswaardes op die $75 \mathrm{~dB}$ verwysingspeil nie.

Die gegewens in Tabel 24 word verder ontleed in Tabel 25 om te bepaal of daar beduidende verskille voorkom tussen die vier laboratoriums wat toetse teen die $95 \mathrm{~dB}$ verwysingspeil afgeneem het. 


\section{TABEL 24}

GEMIDDELDE GELYKE LUIDHEIDSWAARDES VAN TOETSKLANKE OP DIE 95 DB VERWYSINGSPEIL

\begin{tabular}{|l|c|c|c|c|c|c|}
\hline Laboratorium & 2 & 3 & 4 & 5 & 6 & 7 \\
\hline Aantal toetslinge & $*$ & 9 & 9 & 9 & $*$ & 9 \\
\hline Gemiddelde waarde & & 86,50 & 84,95 & 89,50 & & 87,20 \\
\hline
\end{tabular}

*Laboratoria 2 en 6 het geen toetse teen die $95 \mathrm{~dB}$ verwysingspeil afgeneem nie.

\section{$\underline{\text { TABEL } 25}$}

\section{VARIANSIEONTLEDING VAN GELYKE LUIDHEIDSWAARDES OP DIE 95 DB VERWYSINGSPEIL}

\begin{tabular}{|l|c|c|c|c|}
\hline \multicolumn{1}{|c|}{ Soort variansie } & $\begin{array}{c}\text { Som van } \\
\text { kwadrate }\end{array}$ & G.V. & $\begin{array}{c}\text { Skatting van } \\
\text { Groepvariansie }\end{array}$ & F \\
\hline Tussen groepe & 118,0624 & 3 & 39,3541 & \multirow{2}{*}{1,8092} \\
\hline Binne groepe & 696,0559 & 32 & 21,7517 & \\
\hline
\end{tabular}

Uit Tabel 25 blyk dat daar geen beduidende verskille voorkom tussen die gelyke luidheidswaardes van die onderskeie laboratoriums teen die $95 \mathrm{~dB}$ verwysingspeil nie.

Uit die voorafgaande vergelyking van gelyke luidheidswaardes tussen laboratoriums, is dit duidelik dat die gegewens van laboratorium 7 wel ingesluit kon word vir finale verwerking van gegewens. Die gegewens van laboratorium 2 moet egter bevraagteken word omdat hierdie laboratorium telkens beduidend verskil van die resultate van ander laboratoriums. Vroeër is vermeld dat die gemiddelde houding van toetslinge teenoor die navorsingsprojek in laboratorium 2 beduidend verskil van ander laboratoriums.

Aangesien slegs laboratorium 2 as geïsoleerde geval beduidend verskil van ander laboratoriums, kan die oorsaak vir beduidendheid nie in kulturele verskille gesoek word nie. Tydens 'n spesiale besoek aan hierdie laboratorium is vasgestel dat daar ' $n$ konstante fout voorkom by die bepaling van gelyke luidheidswaardes van hierdie laboratorium. In die lig hiervan, sowel as die resultate van die voorafgaande vergelyking tussen groepe, is besluit om die gelyke luidheidsresultate van hierdie laboratorium te elimineer vir die doeleindes van die huidige projek. Vir die evaluering van die verskillende meetmetodes van luidheid, is dus gebruik gemaak van die gegewens van laboratoria 3, 4, 5, 6 en 7 . 
Die totale monster van gegewens wat vir die doeleindes van die huidige ondersoek ingesluit is om bestaande internasionaal gestandaardiseerde meetmetodes vir die waarneming van luidheid te evalueer, word in Tabe1 26 uiteengesit. Hierdie uiteensetting word vir elkeen van die 16 toetssessies, bestaande uit 48 (16 x 3) toetsklanke met die toepaslike verwysingspeil daarby aangetoon. Die totale monster van gelyke luidheids waardes $(\Sigma N)$ kom op 3114 te staan, wat beteken dat 1188 (laboratorium 1 en 2) gelyke luidheidswaardes uitgesluit word vir hierdie ontleding.

Elkeen van die 3114 gelyke luidheidswaardes word deur middel van 'n rekenaarprogram verwerk na die 18 verskillende meetmetodes van luidheid relatief tot die toepaslike verwysingspeile van $55 \mathrm{~dB}, 75 \mathrm{~dB}$ en $95 \mathrm{~dB}$ onderskeidelik.

\section{Kriteria vir die seleksie van luidheidsmeetmetodes}

Aangesien die onderlinge vergelyking tussen luidheidsmeetmetodes slegs op 'n relatiewe grondslag gedoen kan word, is drie kriteria van seleksie vir die huidige ondersoek implementeer. Hierdeur is gesoek na algemene tendense vanuit drie verskillende benaderings:

\section{Konstantheid van meting as kriterium vir seleksie}

Die eerste vereiste vir ' $n$ doeltreffende meetmetode van luidheid is dat die ideale meetmetode konstant moet meet oor die totale spektrum van toetsklanke. Die meetmetode wat dus die kleinste variasie toon rondom sy eie gemiddelde, kan as die beste meetmetode beskou word.

\section{Konstantheid van meting rondom die berekende luidheid van verwysingsklanke as}

\section{kriterium van seleksie}

Die twee vereistes vir die seleksie van 'n ideale meetmetode is dat dit konstant moet meet rondom die berekende luidheid van verwysingsklanke. In hierdie geval moet die luidheid van die verwysingspeile van $55 \mathrm{~dB}, 75 \mathrm{~dB}$ en $95 \mathrm{~dB}$ herlei word na elkeen van die 18 meetmetodes van luidheid vir die bepaling van 'n ware telling per meetmetode. Die meetmetode wat die kleinste variasie toon rondom sy eie berekende luidheid van verwysingspeile, word as beste meetmetode beskou. 
$\underline{\text { TABEL } 26}$

\section{GEMIDDELDE TELLINGS EN STANDAARDAFWYKINGS VAN GELYKE LUIDHEIDSWAARDES}

\begin{tabular}{|c|c|c|c|c|c|c|c|c|c|}
\hline $\begin{array}{c}\text { Toets- } \\
\text { klank }\end{array}$ & $\begin{array}{c}\text { Verw. } \\
\text { peil } \\
(\mathrm{dB})\end{array}$ & $\bar{X}$ & $\mathrm{~S}$ & $\mathrm{~N}$ & $\begin{array}{c}\text { Toets- } \\
\text { klank }\end{array}$ & $\begin{array}{c}\text { Verw. } \\
\text { peil } \\
(\mathrm{dB})\end{array}$ & $\bar{X}$ & $\mathrm{~S}$ & $\mathrm{~N}$ \\
\hline 1,1 & 75 &,- 015 & 2,80 & 68 & 9,7 & 75 & 6,333 & 3,63 & 66 \\
1,2 & 75 & 1,118 & 3,56 & 68 & 9,2 & 75 & 8,030 & 3,60 & 66 \\
1,3 & 75 & 3,353 & 4,81 & 68 & 9,3 & 75 & 7,227 & 3,49 & 66 \\
2,1 & 75 & 0,030 & 3,99 & 67 & 10,1 & 75 & 11,127 & 5,42 & 63 \\
2,2 & 75 & 3,269 & 3,32 & 67 & 10,2 & 75 & 11,048 & 4,64 & 63 \\
2,3 & 75 & 4,164 & 4,82 & 67 & 10,3 & 75 & 11,698 & 4,14 & 63 \\
3,1 & 75 & 12,333 & 4,38 & 66 & 11,1 & 55 & 0,149 & 2,62 & 67 \\
3,2 & 75 & 9,727 & 3,81 & 66 & 11,2 & 55 & 1,493 & 2,87 & 67 \\
3,3 & 75 & 8,909 & 4,15 & 66 & 11,3 & 55 & 1,597 & 4,32 & 67 \\
4,1 & 75 & 9,435 & 3,86 & 62 & 12,1 & 55 & 8,348 & 3,73 & 66 \\
4,2 & 75 & 11,839 & 4,27 & 62 & 12,2 & 55 & 8,530 & 3,67 & 66 \\
4,3 & 75 & 1,968 & 3,90 & 62 & 12,3 & 55 & 10,545 & 3,64 & 66 \\
5,1 & 75 & 7,299 & 3,92 & 67 & 13,1 & 55 & 9,471 & 3,29 & 68 \\
5,2 & 75 & 6,463 & 3,57 & 67 & 13,2 & 55 & 10,368 & 3,92 & 68 \\
5,3 & 75 & 8,851 & 3,88 & 67 & 13,3 & 55 & 10,485 & 4,27 & 68 \\
6,1 & 75 & 9,500 & 3,56 & 66 & 14,1 & 95 &,- 717 & 4,45 & 60 \\
6,2 & 75 & 10,061 & 4,02 & 66 & 14,2 & 95 & 5,750 & 2,98 & 60 \\
6,3 & 75 & 11,182 & 3,31 & 66 & 14,3 & 95 & 8,650 & 4,61 & 60 \\
7,1 & 75 & 8,877 & 3,49 & 65 & 15,1 & 95 & 10,475 & 3,65 & 61 \\
7,2 & 75 & 9,538 & 3,47 & 65 & 15,2 & 95 & 7,885 & 2,62 & 61 \\
7,3 & 75 & 10,646 & 3,50 & 65 & 15,3 & 95 & 9,934 & 3,01 & 61 \\
8,1 & 75 & 10,955 & 3,78 & 66 & 16,1 & 95 & 10,850 & 4,14 & 60 \\
8,2 & 75 & 11,258 & 3,61 & 66 & 16,2 & 95 & 10,250 & 5,26 & 60 \\
8,3 & 75 & 11,273 & 3,51 & 66 & 16,3 & 95 & 13,267 & 4,73 & 60 \\
\hline
\end{tabular}

Die verband tussen meetmetodes en subjektiewe gelyke, luidheidswaardes as kriterium van seleksie

Die derde vereiste waaraan die ideale meetmetode moet voldoen is dat daar ' $n$ hoë positiewe korrelasie tussen die meetmetode en die subjektiewe gelyke luidheidswaardes moet wees. Hierdie vereiste is belangrik omdat dit algemeen aanvaar word dat laer frekwensies van klanke sagter klink vir die mens as hoër frekwensies teen dieselfde itensiteitspeil. In die psigo-akoestiek, waar meetmetodes menslike waarneming van luidheid simuleer, is 'n negatiewe korrelasie tussen 'n meetmetode en menslike waarneming van luidheid dus onlogies en teenstrydig met die natuurlike wetmatigheid van die gehoormeganisme. Om die 
korrelasie tussen meetmetodes en gelyke luidheidswaardes te kan uitvoer, moet elkeen van die eenhede van die verskillende meetmetodes herlei word na 'n gemeenskaplike skaaleenheid.

Bogenoemde drie kriteria van seleksie vorm die basis van die statistiese ontleding van resultate wat hieronder uiteengesit word:

\section{Ontleding van resultate}

Die verspreiding van meetmetodes rondom eie gemiddeldes

In hierdie onderlinge vergelyking tussen meetmetodes word die skaaleenhede van meetmetodes as gegewe aanvaar en nie na 'n gemeenskaplike skaaleenheid herlei nie. Die standaardafwyking van elke meetmetode rondom sy eie gemiddelde dien as verspreidingsmaatstaf. Hierdie gegewens word vir die verskillende verwysingspeile van $55 \mathrm{~dB}, 75 \mathrm{~dB}$ en $95 \mathrm{~dB}$ in Tabelle 27, 28 en 29 uiteengesit.

Uit die rangorde van standaardafwykings in Tabel 27 is dit duidelik dat Zwicker se metode die kleinste verspreiding rondom sy eie gemiddelde toon, terwyl Stevens se metode tweede geplaas is. Die korrigering van meetmetodes deur die Internasionale Standaardisasie Organisasie (I.S.O.), Federal Aviation Agency (F.A.A.) en Kryter verbeter ook in geen geval die konstantheid van meting van 'n bepaalde meetmetode op die $55 \mathrm{~dB}$ verwysingspeil nie. 
$\underline{\text { TABEL } 27}$

GEMIDDELDE GELYKE LUIDHEIDSPEILE EN STANDAARDAFWYKINGS VAN MEETMETODES OP DIE 55 DB VERWYSINGSPEIL $(\mathrm{N}=603)$

\begin{tabular}{|c|c|c|c|c|c|c|c|c|c|}
\hline \multicolumn{2}{|c|}{$\begin{array}{l}\text { Meet- } \\
\text { metode }\end{array}$} & $\bar{X}$ & S & $\begin{array}{l}\text { Rang- } \\
\text { orde }\end{array}$ & \multicolumn{2}{|c|}{$\begin{array}{l}\text { Meet- } \\
\text { metode }\end{array}$} & $\bar{X}$ & $\mathrm{~S}$ & $\begin{array}{l}\text { Rang- } \\
\text { orde }\end{array}$ \\
\hline Liniêr & & 49,02 & 4,21 & 9 & $\mathrm{~dB}(\mathrm{~A})$ & & 53,91 & 4,50 & 13 \\
\hline $\mathrm{dB}(\mathrm{A})$ & & 48,38 & 4,13 & 8 & $\mathrm{~dB}(\mathrm{D})$ & $\ll$ & 60,64 & 4,98 & 15 \\
\hline $\mathrm{dB}(\mathrm{D})$ & & 55,19 & 4,40 & 12 & Stevens & & 56,06 & 2,24 & 3 \\
\hline Zwicker & & 60,20 & 1,34 & 1 & PNdB & & 64,05 & 3,62 & 7 \\
\hline Stevens & & 51,75 & 1,95 & 2 & $\mathrm{~dB}(\mathrm{~A}))$ & & 54,24 & 4,50 & 13 \\
\hline $\mathrm{PNdB}$ & & 58,39 & 3,30 & 6 & $\mathrm{~dB}(\mathrm{D})$ & 鼠 & 61,16 & 5,64 & 18 \\
\hline $\mathrm{dB}(\mathrm{A}))$ & & 53,65 & 5,28 & 16 & Stevens & 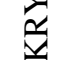 & 56,12 & 2,74 & 4 \\
\hline $\mathrm{dB}(\mathrm{D})$ & ค่ & 60,46 & 5,55 & 17 & $\mathrm{PNdB})$ & & 64,29 & 4,37 & 11 \\
\hline Stevens & $\ddot{\sim}$ & 57,02 & 2,87 & 5 & & & & & \\
\hline $\mathrm{PNdB}$ & & 63,67 & 4,34 & 10 & & & & & \\
\hline
\end{tabular}

$\underline{\text { TABEL } 28}$

\section{GEMIDDELDE GELYKE LUIDHEIDSPEILE EN STANDAARDAFWYKINGS VAN MEETMETODES OP DIE 75 DB VERWYSINGSPEIL $(\mathrm{N}=1968)$}

\begin{tabular}{|c|c|c|c|c|c|c|c|c|c|}
\hline \multicolumn{2}{|c|}{$\begin{array}{l}\text { Meet- } \\
\text { metode }\end{array}$} & $\bar{X}$ & $S$ & $\begin{array}{l}\text { Rang- } \\
\text { orde }\end{array}$ & \multicolumn{2}{|c|}{$\begin{array}{l}\text { Meet- } \\
\text { metode }\end{array}$} & $\bar{X}$ & $S$ & $\begin{array}{l}\text { Rang- } \\
\text { orde }\end{array}$ \\
\hline Liniêr & & 69,19 & 5,58 & 17 & $\mathrm{~dB}(\mathrm{~A})$ & & 72,67 & 4,60 & 12 \\
\hline $\mathrm{dB}(\mathrm{A})$ & & 67,91 & 3,90 & 7 & $\mathrm{~dB}(\mathrm{D})$ & $\stackrel{亡}{i}$ & 79,36 & 4,95 & 13 \\
\hline $\mathrm{dB}(\mathrm{D})$ & & 74,63 & 4,35 & 10 & Stevens & & 73,85 & 2,94 & 3 \\
\hline Zwicker & & 80,87 & 2,66 & 2 & $\mathrm{PNdB}$ & & 83,29 & 3,92 & 8 \\
\hline Stevens & & 70,23 & 2,50 & 1 & $\mathrm{~dB}(\mathrm{~A}))$ & & 72,34 & 5,35 & 16 \\
\hline PNdB & & 79,05 & 3,33 & 6 & $\mathrm{~dB}(\mathrm{D})$ & $\frac{x}{\underline{y}}$ & 79,14 & 5,59 & 18 \\
\hline $\mathrm{dB}(\mathrm{A}))$ & & 71,77 & 5,04 & 14 & Stevens & 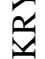 & 73,60 & 3,23 & 5 \\
\hline $\mathrm{dB}(\mathrm{D})$ & & 78,49 & 5,13 & 15 & $\mathrm{PNdB}$ & & 83,03 & 4,45 & 11 \\
\hline Stevens & $\dot{\sim}$ & 74,08 & 3,04 & 4 & & & & & \\
\hline $\mathrm{PNdB}$ & & 82,91 & 4,10 & 9 & & & & & \\
\hline
\end{tabular}


Uit Tabel 28 blyk dat Stevens se metode die kleinste verspreiding rondom sy eie gemiddelde toon en Zwicker die tweede kleinste verspreiding. Die korrigering van meetmetodes deur I.S.O., F.A.A. en Kryter, verbeter ook in geen geval die konstantheid van meting van 'n bepaalde meetmetode op die $75 \mathrm{~dB}$ verwysingspeil nie.

\section{TABEL 29}

\section{GEMIDDELDE GELYKE LUIDHEIDSPEILE EN STANDAARDAFWYKINGS VAN MEETMETODES OP DIE 95 DB VERWYSINGSPEIL $(\mathrm{N}=543)$}

\begin{tabular}{|c|c|c|c|c|c|c|c|c|c|}
\hline \multicolumn{2}{|c|}{$\begin{array}{l}\text { Meet- } \\
\text { metode }\end{array}$} & $\bar{X}$ & $\mathrm{~S}$ & $\begin{array}{l}\text { Rang- } \\
\text { orde }\end{array}$ & \multicolumn{2}{|c|}{$\begin{array}{l}\text { Meet- } \\
\text { metode }\end{array}$} & $\bar{X}$ & S & $\begin{array}{l}\text { Rang- } \\
\text { orde }\end{array}$ \\
\hline Liniêr & & 87,58 & 4,55 & 17 & $\mathrm{~dB}(\mathrm{~A})$ & & 92,47 & 4,21 & 13 \\
\hline $\mathrm{dB}(\mathrm{A})$ & & 86,93 & 3,91 & 12 & $\mathrm{~dB}(\mathrm{D})$ & $\stackrel{\leftrightarrow}{i}$ & 99,19 & 3,83 & 11 \\
\hline $\mathrm{dB}(\mathrm{D})$ & & 93,74 & 3,19 & 10 & Stevens & & 93,01 & 2,65 & 6 \\
\hline Zwicker & & 97,77 & 2,64 & 5 & PNdB & & 103,04 & 2,46 & 3 \\
\hline Stevens & & 87,94 & 2,44 & 2 & $\mathrm{~dB}(\mathrm{~A}))$ & & 92,80 & 4,28 & 16 \\
\hline $\mathrm{PNdB}$ & & 98,16 & 2,10 & 1 & $\mathrm{~dB}(\mathrm{D})$ & $\frac{\sqrt[c]{1]}}{\underline{T}}$ & 99,72 & 4,27 & 15 \\
\hline $\mathrm{dB}(\mathrm{A}))$ & & 92,21 & 4,73 & 18 & Stevens & $\frac{d}{a}$ & 93,26 & 2,60 & 4 \\
\hline dB (D) & $0^{\circ}$ & 99,02 & 4,23 & 14 & $\mathrm{PNdB}$ & & 103,27 & 2,73 & 7 \\
\hline Stevens & $\dot{\sim}$ & 93,22 & 3,10 & 9 & & & & & \\
\hline $\mathrm{PNdB}$ & & 103,43 & 2,84 & 8 & & & & & \\
\hline
\end{tabular}

Uit Tabel 29 blyk dat die PNdB-metode die kleinste verspreid lê rondom sy eie gemiddelde, terwyl Stevens se metode die tweede kleinste standaardafwyking toon. Die korrigering van meetmetodes deur I.S.O., F.A.A. en Kryter verbeter in geen geval die konstantheid van meting van 'n bepaalde meetmetode op die $95 \mathrm{~dB}$ verwysingspeil nie.

Die verspreiding van meetmetodes rondom die berekende luidheid van die verwysingsklanke

Vir die doeleindes van hierdie ontleding is die luidheid van die verwysingsklank van $1000 \mathrm{~Hz}$ relatief tot die verwysingspeile van $55 \mathrm{~dB}, 75 \mathrm{~dB}$ en $95 \mathrm{~dB}$ herlei na die skaaleenhede van elkeen van die 18 meetmetodes deur middel van die volgende formules:

$$
\begin{aligned}
& L_{j k}=M_{k}\left(S_{j}+e_{j}\right) \\
& L_{k r}=M_{k}\left(S_{r}\right)
\end{aligned}
$$


waar:

$\mathrm{L}_{\mathrm{jk}}=$ berekende luidheid van toetsklank $\mathrm{j}$ volgens meetmetode $\mathrm{k}$

$\mathrm{M}_{\mathrm{k}}=$ meetmetode $\mathrm{k}$

$\mathrm{S}_{\mathrm{j}}=$ spektrum van toetsklank $\mathrm{j}$

$\mathrm{e}_{\mathrm{j}}=$ gelyke luidheidswaarde van toetsklank $\mathrm{j}$

$\mathrm{S}_{\mathrm{r}}=$ spektrum van die verwysingskank

$\mathrm{L}_{\mathrm{kr}}=$ berekende luidheid van die verwysingsklank $\mathrm{r}$ volgens meetmetode $\mathrm{k}$.

Die berekende luidheid $\left(\mathrm{L}_{\mathrm{kr}}\right)$ van verwysingsklanke word dus vir elke individuele meeteenheid na sy eie skaaleenheid verwerk. Die verspreiding van elke meeteenheid rondom hierdie skaaleenheidswaardes word in Tabelle 30, 31 en 32 uiteengesit:

$\underline{\text { TABEL } 30}$

VARIANSIE VAN MEETMETODES RONDOM DIE BEREKENDE LUIDHEID VAN DIE VERWYSINGSKLANK OP DIE 55 DB VERWYSINGSPEIL ( $\mathrm{N}=603$ )

\begin{tabular}{|c|c|c|c|c|c|c|c|c|c|}
\hline \multicolumn{2}{|c|}{$\begin{array}{l}\text { Meet- } \\
\text { metode }\end{array}$} & $\mathrm{L}_{\mathrm{kr}}$ & $\begin{array}{l}\text { Vari- } \\
\text { ansie }\end{array}$ & $\begin{array}{l}\text { Rang- } \\
\text { orde }\end{array}$ & \multicolumn{2}{|c|}{$\begin{array}{l}\text { Meet- } \\
\text { metode }\end{array}$} & $\mathrm{L}_{\mathrm{kr}}$ & $\begin{array}{l}\text { Vari- } \\
\text { ansie }\end{array}$ & $\begin{array}{l}\text { Rang- } \\
\text { orde }\end{array}$ \\
\hline Liniêr & & 55,01 & 51,65 & 11 & dB (A) & & 55,00 & 19,16 & 4 \\
\hline $\mathrm{dB}(\mathrm{A})$ & & 55,00 & 59,03 & 4 & $\mathrm{~dB}(\mathrm{D})$ & $\stackrel{亡}{i}$ & 55,03 & 53,44 & 12 \\
\hline $\mathrm{dB}(\mathrm{D})$ & & 55,03 & 17,21 & 3 & Stevens & - & 50,44 & 36,09 & 8 \\
\hline Zwicker & & 56,89 & 12,58 & 2 & PNdB & & 55,31 & 88,08 & 17 \\
\hline Stevens & & 50,44 & 5,11 & 1 & $\mathrm{~dB}(\mathrm{~A}))$ & & 55,00 & 22,39 & 6 \\
\hline $\mathrm{PNdB}$ & & 55,13 & 19,21 & 5 & $\mathrm{~dB}(\mathrm{D})$ & 㩊 & 55,03 & 65,88 & 15 \\
\hline $\mathrm{dB}(\mathrm{A}))$ & & 55,00 & 26,58 & 7 & Stevens & $\frac{d}{2}$ & 50,44 & 38,92 & 9 \\
\hline dB (D) & 0 & 55,03 & 56,81 & 13 & $\mathrm{PNdB}$ & & 55,31 & 97,65 & 18 \\
\hline Stevens & & 50,44 & 50,69 & 10 & & & & & \\
\hline $\mathrm{PNdB}$ & & 55,31 & 86,58 & 16 & & & & & \\
\hline
\end{tabular}

Uit Tabel 30 blyk dat Stevens se metode die minste varieer rondom die berekende luidheid van die verwysingsklank van $1000 \mathrm{~Hz}$ op die $55 \mathrm{~dB}$ verwysingspeil, met Zwicker se metode die tweede kleinste variansie. Stevens se $\mathrm{L}_{\mathrm{kr}}$ van 50,44 is ook nader aan sy eie berekening van die gemiddelde luidheidspeil $(\bar{X}=51,75)$ van toetslinge as Zwicker se $\mathrm{L}_{\mathrm{kr}}$ van 
56,89 relatief tot sy berekening van die gemiddelde luidheidspeil ( $\bar{X}=60,20$ ) van toetslinge (vergelyk Tabel 27).

$\underline{\text { TABEL } 31}$

\section{VARIANSIE VAN MEETMETODES RANDOM DIE BEREKENDE LUIDHEID VAN DIE VERWYSINGSKLANK OP DIE 75 DB VERWYSINGSPEIL ( $=1968)$}

\begin{tabular}{|c|c|c|c|c|c|c|c|c|c|}
\hline \multicolumn{2}{|c|}{$\begin{array}{l}\text { Meet- } \\
\text { metode }\end{array}$} & $\mathrm{L}_{\mathrm{kr}}$ & $\begin{array}{l}\text { Vari- } \\
\text { ansie }\end{array}$ & $\begin{array}{l}\text { Rang- } \\
\text { orde }\end{array}$ & \multicolumn{2}{|c|}{$\begin{array}{l}\text { Meet- } \\
\text { metode }\end{array}$} & $\mathrm{L}_{\mathrm{kr}}$ & $\begin{array}{c}\text { Vari- } \\
\text { ansie }\end{array}$ & $\begin{array}{l}\text { Rang- } \\
\text { orde }\end{array}$ \\
\hline Liniêr & & 75,00 & 63,71 & 14 & $\mathrm{~dB}(\mathrm{~A})$ & & 75,00 & 25,76 & 3 \\
\hline $\mathrm{dB}(\mathrm{A})$ & & 75,00 & 64,91 & 15 & $\mathrm{~dB}(\mathrm{D})$ & $\stackrel{<}{i}$ & 75,00 & 42,54 & 8 \\
\hline $\mathrm{dB}(\mathrm{D})$ & & 75,00 & 18,37 & 2 & Stevens & & 67,58 & 47,67 & 11 \\
\hline Zwicker & & 74,41 & 48,58 & 12 & PNdB & & 74,71 & 88,30 & 17 \\
\hline Stevens & & 67,58 & 13,01 & 1 & $\mathrm{~dB}(\mathrm{~A}))$ & & 75,00 & 34,58 & 5 \\
\hline PNdB & & 74,71 & 29,49 & 4 & $\mathrm{~dB}(\mathrm{D})$ & $\frac{\sqrt{x}}{\underline{y}}$ & 75,00 & 47,20 & 10 \\
\hline $\mathrm{dB}(\mathrm{A}))$ & & 75,00 & 34,88 & 6 & Stevens & $\frac{\pi}{1}$ & 67,58 & 46,30 & 9 \\
\hline $\mathrm{dB}(\mathrm{D})$ & & 75,00 & 37,50 & 7 & PNdB & & 74,71 & 88,37 & 18 \\
\hline Stevens & $\ddot{\sim}$ & 67,58 & 51,23 & 13 & & & & & \\
\hline $\mathrm{PNdB}$ & & 74,71 & 83,37 & 16 & & & & & \\
\hline
\end{tabular}

Uit Tabel 31 blyk dat Stevens se metode die minste varieer rondom die berekende luidheid van die verwysingsklank van $1000 \mathrm{~Hz}$ op die $75 \mathrm{~dB}$ verwysingspeil, met die dB (D)metode tweede geplaas in rangorde. Stevens se $\mathrm{L}_{\mathrm{kr}}$ is egter verder verwyder van sy eie berekening van die gemiddelde luidheidspeil $(\bar{X}=70,23)$ van toetslinge as die $\mathrm{dB}(\mathrm{D})$ metode se $\mathrm{L}_{\mathrm{kr}}$ van 75,00 relatief tot sy eie berekening van die gemiddelde luidheidspeil ( $\bar{X}=$ 74,63) van toetslinge (vergelyk Tabel 28). 


\section{TABEL 32}

VARIANSIE VAN MEETMETODES RONDOM DIE BEREKENDE LUIDHEID VAN DIE VERWYSINGSKLANK OP DIE 95 DB VERWYSINGSPEIL $(\mathrm{N}=543)$

\begin{tabular}{|c|c|c|c|c|c|c|c|c|}
\hline $\begin{array}{l}\text { Meet- } \\
\text { metode }\end{array}$ & $\mathrm{L}_{\mathrm{kr}}$ & $\begin{array}{l}\text { Vari- } \\
\text { ansie }\end{array}$ & $\begin{array}{l}\text { Rang- } \\
\text { orde }\end{array}$ & \multicolumn{2}{|c|}{$\begin{array}{l}\text { Meet- } \\
\text { metode }\end{array}$} & $\mathrm{L}_{\mathrm{kr}}$ & $\begin{array}{c}\text { Vari- } \\
\text { ansie }\end{array}$ & $\begin{array}{l}\text { Rang- } \\
\text { orde }\end{array}$ \\
\hline Liniêr & 95,00 & 73,54 & 15 & $\mathrm{~dB}(\mathrm{~A})$ & & 95,00 & 22,16 & 5 \\
\hline $\mathrm{dB}(\mathrm{A})$ & 95,00 & 78,69 & 17 & $\mathrm{~dB}(\mathrm{D})$ & & 95,00 & 30,58 & 8 \\
\hline $\mathrm{dB}(\mathrm{D})$ & 95,00 & 10,61 & 2 & Stevens & & 87,12 & 40,94 & 11 \\
\hline Zwicker & 93,06 & 28,40 & 7 & $\mathrm{PNdB}$ & & 94,95 & 70,78 & 14 \\
\hline Stevens & 87,12 & 5,97 & 1 & $\mathrm{~dB}(\mathrm{~A}))$ & & 95,00 & 21,14 & 4 \\
\hline PNdB & 94,95 & 14,21 & 3 & $\mathrm{~dB}(\mathrm{D})$ & 獣 & 95,00 & 38,5 & 10 \\
\hline $\mathrm{dB}(\mathrm{A}))$ & 95,00 & 27,70 & 6 & Stevens & $\frac{1}{1}$ & 87,12 & 43,72 & 12 \\
\hline $\mathrm{dB}(\mathrm{D})$ & 95,00 & 31,99 & 9 & $\mathrm{PNdB}$ & & 94,95 & 75,85 & 16 \\
\hline Stevens & 87,12 & 45,67 & 13 & & & & & \\
\hline $\mathrm{PNdB}$ & 94,95 & 79,09 & 18 & & & & & \\
\hline
\end{tabular}

Uit Tabel 32 blyk dat Stevens se metode die minste varieer rondom die berekende luidheid van die verwysingsklank van $1000 \mathrm{~Hz}$ teen die $95 \mathrm{~dB}$ verwysingspeil, met die dB (D)-metode tweede in rangorde geplaas. Stevens se $\mathrm{L}_{\mathrm{kr}}$ van 87,12 is ook nader aan sy eie berekening van die gemiddelde luidheidspeil $(\bar{X}=87,94)$ van toetslinge as die $\mathrm{dB}(\mathrm{D})$ metode se $\mathrm{L}_{\mathrm{kr}}$ van 95,00 relatief tot sy berekening van die gemiddelde luidheidspeil ( $\bar{X}=$ 93,74) van toetslinge (vergelyk Tabel 32).

Die korrelasie tussen meetmetodes en gemiddelde gelyke luidheidswaardes van toetslinge

Vir hierdie ontleding van gegewens is die gelyke luidheidspeil van elke meetmetode aangepas tot 'n gemeenskaplike skaaleenheid relatief tot die berekende luidheid van die verwysingsklank $\left(\mathrm{L}_{\mathrm{kr}}\right)$ van $1000 \mathrm{~Hz}$ op die $55 \mathrm{~dB}, 75 \mathrm{~dB}$ en $95 \mathrm{~dB}$ verwysingspeile. Die volgende formule is vir hierdie berekening toegepas:

$$
\mathrm{L}_{\mathrm{kr}}=\mathrm{M}_{\mathrm{k}}\left(\mathrm{S}_{\mathrm{r}}\right)=\mathrm{M}_{\mathrm{k}}\left(\mathrm{S}_{\mathrm{j}}+\mathrm{c}_{\mathrm{jk}}\right)
$$

waar: $\mathrm{L}_{\mathrm{kr}}=$ berekende luidheid van die verwysingsklank $\mathrm{r}$ volgens meetmetode $\mathrm{k}$ (sien voorafgaande ontleding (b)). 
$\mathrm{M}_{\mathrm{k}}=$ meetmetode $\mathrm{k}$

$\mathrm{S}_{\mathrm{r}}=$ spektrum van die verwysingsklank

$S_{\mathrm{j}}=$ spektrum van die toetsklank

$\mathrm{C}_{\mathrm{jk}}=$ die verandering in klankdrukpeil wat nodig is om die luidheid van toetsklank $S_{\mathrm{j}}$ gelyk te maak aan die luidheid van die verwysingsklank $r$.

Die produk-moment korrelasiekoëffisiënte tussen die $C_{j k}$ waardes van elke meetmetode en die gelyke luidheidswaardes van toetslinge is afsonderlik bereken vir toetse op die $55 \mathrm{~dB}$, $75 \mathrm{~dB}$ en $95 \mathrm{~dB}$ verwysingspeile en word in Tabelle 33, 34 en 35 uiteengesit. In hierdie tabelle word slegs die positiewe korrelasiekoëffisiënte in rangorde geplaas vir die doeleindes van seleksie van meetmetodes.

\section{TABEL 33}

KORRELASIE TUSSEN $\mathrm{C}_{\mathrm{JK}}$-WAARDES PER MEETMETODE EN GEMIDDELDE GELYKE

LUIDHEIDSWAARDES VAN TOETSLINGE OP DIE 55 DB VERWYSINGSPEIL (N=9)

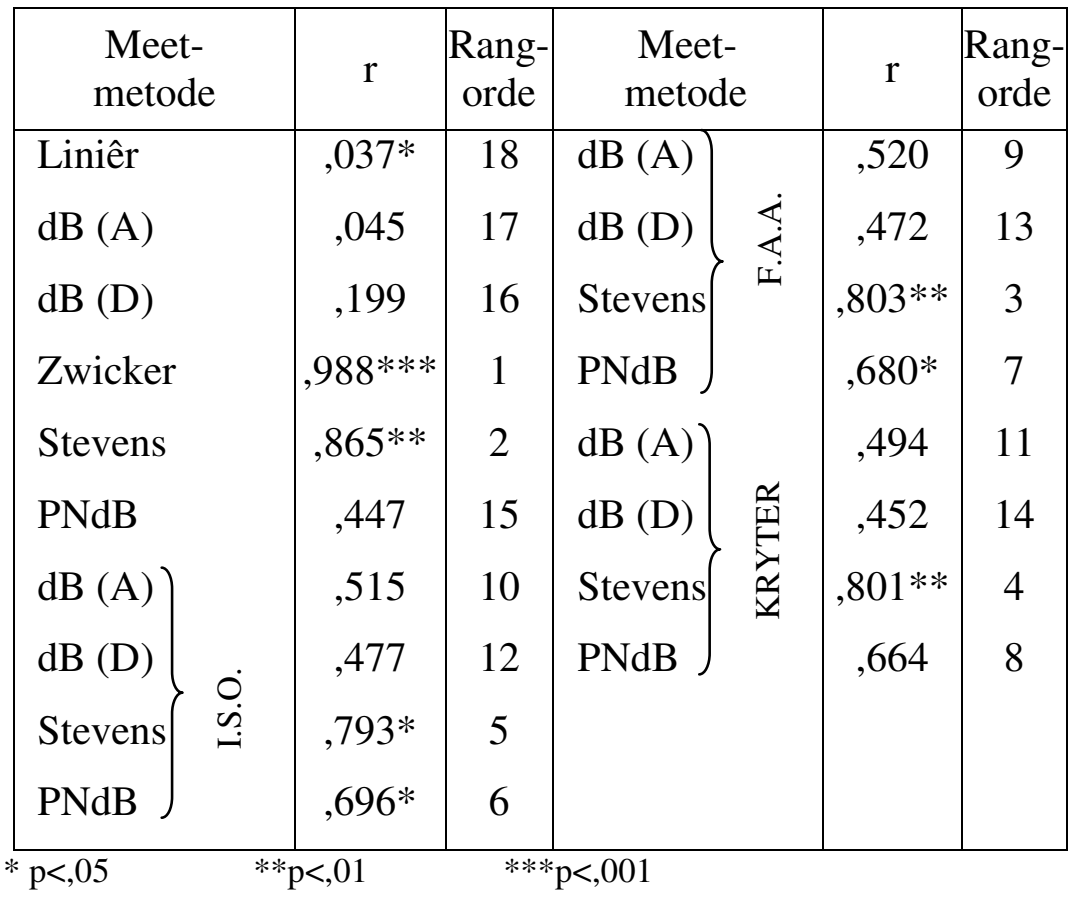

Uit Tabel 33 blyk dat Zwicker se metode die hoogste korrelasie toon tussen $\mathrm{C}_{\mathrm{jk}}$-waardes en gemiddelde gelyke luidheidswaardes van toetslinge. Die koëffisiënt van determinasie, as persentasie uitgedruk $\left(r^{2} \times 100\right)$, toon dat Zwicker se metode 97,61 \% van die variansie in subjektiewe luidheidswaardes van toetslinge verklaar op die $55 \mathrm{~dB}$ verwysingspeil. Stevens se metode wat tweede in rangorde van korrelasies geplaas is, verklaar $74,82 \%$ van die Perspektiewe in die Bedryfsielkunde 19762.4 
variansie in subjektiewe luidheidswaardes van toetslinge op die $55 \mathrm{~dB}$ verwysingspeil. Verder is dit belangrik dat die I.S.0.-, F.A.A.- en Kryter-korreksies in geen geval die meetmetodes verbeter om ' $\mathrm{n}$ beter verklaring te gee van subjektiewe luidheid as die oorspronklike Zwicker en Stevens metodes nie.

Die liniêre, dB (A)-, dB (D)- en PNdB-metodes toon verder onbeduidende korrelasies met die gemiddelde gelyke luidheidswaardes van toetslinge op die $55 \mathrm{~dB}$ verwysingspeil.

\section{TABEL 34}

\section{KORRELASIE TUSSEN CJK-WAARDES PER MEETMETODE EN GEMIDDELDE GELYKE LUIDHEIDSWAARDES VAN TOETSLINGE OP DIE 75 DB VERWYSINGSPEIL $(\mathrm{N}=30)$}

\begin{tabular}{|c|c|c|c|c|c|c|c|}
\hline \multicolumn{2}{|c|}{$\begin{array}{l}\text { Meet- } \\
\text { metode }\end{array}$} & $\mathrm{r}$ & $\begin{array}{c}\text { Rang- } \\
\text { orde }\end{array}$ & \multicolumn{2}{|c|}{$\begin{array}{l}\text { Meet- } \\
\text { metode }\end{array}$} & $\mathrm{r}$ & $\begin{array}{l}\text { Rang- } \\
\text { orde }\end{array}$ \\
\hline Liniêr & &,- 454 & & $\mathrm{~dB}(\mathrm{~A})$ & &, $665^{*}$ & 10 \\
\hline $\mathrm{dB}(\mathrm{A})$ & &,- 004 & & $\mathrm{~dB}(\mathrm{D})$ & $\underset{\ll}{\dot{\ll}}$ &, $570 *$ & 13 \\
\hline $\mathrm{dB}(\mathrm{D})$ & & ,081 & 16 & Stevens & {$\left[I^{\circ}\right.$} &, $809 *$ & 2 \\
\hline Zwicker & &, $751 *$ & 5 & $\mathrm{PNdB}$ & &, $759 *$ & 5 \\
\hline Stevens & &, $684 *$ & 8 & $\mathrm{~dB}(\mathrm{~A}))$ & & ,667* & 9 \\
\hline $\mathrm{PNdB}$ & &, $572 *$ & 12 & $\mathrm{~dB}(\mathrm{D})$ & $\frac{\alpha}{I I}$ &, $555^{*}$ & 14 \\
\hline $\mathrm{dB}(\mathrm{A}))$ & &, $625^{*}$ & 11 & Stevens & $\underset{\alpha}{\approx}$ & ,793* & 3 \\
\hline $\mathrm{dB}$ (D) & 0 &, $541 *$ & 15 & $\mathrm{PNdB}$ & & ,743* & 7 \\
\hline Stevens & 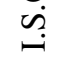 &, $819 *$ & 1 & & & & \\
\hline $\mathrm{PNdB})$ & &, $773 *$ & 4 & & & & \\
\hline
\end{tabular}

Uit die gegewens in Tabel 34 blyk dat Stevens se metode volgens I.S.O. korreksies, die hoogste positiewe korrelasie toon met die gemiddelde luidheid van toetslinge op die $75 \mathrm{~dB}$ verwysingspeil en $67,08 \%$ van die variansie in subjektiewe luidheid van toetslinge verklaar. Stevens se metode volgens die F.A.A. -korreksies vir suiwertone is ook tweede in rangorde geplaas. Uit Tabel 34 blyk verder dat die korreksies vir suiwertone deur I.S.O., F.A.A. en Kryter wel die meetmetodes verbeter op die $75 \mathrm{~dB}$ verwysingspeil. Die dB (D)-metode toon verder 'n onbeduidende korrelasie, terwyl die liniêre en $\mathrm{dB}(\mathrm{A})$-metodes negatief korreleer met die gemiddelde gelyke luidheidswaardes van toetslinge op die $75 \mathrm{~dB}$ verwysingspeil. 
Uit Tabel 35 blyk dat die PNdB-metode die hoogste korreleer met die subjektiewe gelyke luidheidswaardes van toetslinge op die $95 \mathrm{~dB}$-verwysingspeil en 72,93\% van die variansie in subjektiewe luidheid van toetslinge verklaar. Alhoewel die PNdB-metode volgens I.S.O. toonkorreksies tweede geplaas en volgens F.A.A. toonkorreksies derde geplaas is in rangorde van korrelasies, is dit duidelik dat die oorspronklike PNdB-metode slegs verswak word deur byvoeging van suiwertoon-korreksies. Dit is ook belangrik om daarop te let dat beide Stevens en Zwicker se metode vierde geplaas is met 'n koëffisiënt van determinasie van 0,6448. Die dB (A)- en dB (D)-metodes toon verder onbeduidende korrelasies, terwyl die liniêre metode negatief met die subjektiewe gelyke luidheidswaardes van toetslinge op die $95 \mathrm{~dB}$ verwysingspeil korreleer.

\section{$\underline{\text { TABEL } 35}$}

\section{KORRELASIE TUSSEN $\mathrm{C}_{\mathrm{JK}}$-WAARDES PER MEETMETODE EN GEMIDDELDE GELYKE LUIDHEIDSWAARDES VAN TOETSLINGE OP DIE 95 DB VERWYSINGSPEIL $(\mathrm{N}=9)$}

\begin{tabular}{|c|c|c|c|c|c|c|c|}
\hline \multicolumn{2}{|c|}{$\begin{array}{l}\text { Meet- } \\
\text { metode }\end{array}$} & $\mathrm{r}$ & $\begin{array}{c}\text { Rang- } \\
\text { orde }\end{array}$ & \multicolumn{2}{|l|}{$\begin{array}{l}\text { Meet- } \\
\text { metode }\end{array}$} & $r$ & $\begin{array}{l}\text { Rang- } \\
\text { orde }\end{array}$ \\
\hline Liniêr & &,- 439 & & $\mathrm{~dB}(\mathrm{~A}))$ & & ,504 & 15 \\
\hline $\mathrm{dB}(\mathrm{A})$ & & ,033 & 17 & $\mathrm{~dB}(\mathrm{D})$ & $\underset{4}{\dot{4}}$ & ,700* & 11 \\
\hline dB (D) & & ,567 & 13 & Stevens & I &, $749 *$ & 8 \\
\hline Zwicker & &, $803 * *$ & 4 & $\mathrm{PNdB}$ & &, $811 * *$ & 3 \\
\hline Stevens & &, $803 * *$ & 4 & $\mathrm{~dB}(\mathrm{~A}))$ & & ,479 & 16 \\
\hline $\mathrm{PNdB}$ & &, $854 * *$ & 1 & $\mathrm{~dB}(\mathrm{D})$ & $\stackrel{\underline{x}}{\underline{y}}$ & ,664 & 12 \\
\hline $\mathrm{dB}(\mathrm{A}))$ & &, 505 & 14 & Stevens & $\frac{\pi}{2}$ &, $738 *$ & 10 \\
\hline $\mathrm{dB}(\mathrm{D})$ & $0^{\circ}$ &, $745^{*}$ & 9 & PNdB & &, $789 *$ & 6 \\
\hline Stevens & $\stackrel{\mathscr{\rho}}{\sim}$ &, $753 *$ & 7 & & & & \\
\hline $\mathrm{PNdB}$ & &, $835 * *$ & & & & & \\
\hline
\end{tabular}




\section{BESPREKING}

Al drie die voorafgaande kriteria vir die ontleding van resultate het inherente beperkings wat as volg saamgevat kan word:

- Die vergelyking van standaardafwykings rondom eie gemiddel des per meetmetode is afhanklik van verskillende skaaleenhede van meetmetodes. Die skaaleenheid van 'n meetmetode het dus 'n invloed op die verspreiding van sodanige meetmetode.

- Die herleiding van meeteenhede na die berekende luidheid $\left(\mathrm{L}_{\mathrm{kr}}\right)$ van verwysingsklanke stel elke meeteenheid in die regte verhouding tot sy eie skaaleenheid, maar bemoeilik steeds intervergelykings tussen skaaleenhede van meetmetodes.

- Die herleiding van meetmetodes na 'n gemeenskaplike skaal $\left(\mathrm{C}_{\mathrm{jk}}\right.$-waardes $)$ skakel die skaaleenheidsprobleem uit. In hierdie geval word egter kunsmatige eise gestel aan meetmetodes wat nie in die alledaagse praktyk van meting voorkom nie.

Ten spyte van bogenoemde beperkings kan nogtans belangrike afleidings van die algemene tendense van seleksie wat deur sodanige ontleding van gegewens aangedui word, gemaak word. Aangesien daar geen ander metode bestaan waarvolgens meetmetodes vir die doeleindes van die huidige ondersoek direk met mekaar vergelyk kan word nie, word gevolgtrekkings baseer op die kombinasie van tendense wat uit die ontleding van resultate voortvloei. Hierdie tendense word deur middel van die eerste twee keuses van meetmetodes per ontledingsmetode in Tabel 36 uiteengesit.

Algemene gevolgtrekkings gebaseer op die gegewens in Tabel 36, word vervolgens uiteengesit:

\section{Die 55 dB verwysingspeil}

Aangesien Zwicker se metode die hoogste korrelasie $(\mathrm{r}=, 988, \mathrm{p}<, 001)$ toon tussen $\mathrm{C}_{\mathrm{jk}}$-waardes en gemiddelde gelyke luidheidswaardes van toetslinge en ook die kleinste standaardafwyking $(1,34)$ toon rondom sy eie gemiddelde, kan aanvaar word dat die Zwickermetode die beste bepaling is van menslike waarneming van luidheid op die $55 \mathrm{~dB}$ verwysingspeil. 
$\underline{\text { TABEL } 36}$

\section{ALGEMENE TENDENSE VIR SELEKSIE VAN MEETMETODES VOLGENS ONTLEDING VAN RESULTATE}

\begin{tabular}{|c|c|c|c|c|c|c|}
\hline $\begin{array}{c}\text { Kriterium van } \\
\text { Seleksie }\end{array}$ & \multicolumn{2}{|c|}{$\begin{array}{c}55 \mathrm{~dB} \text { ver- } \\
\text { wysingspeil }\end{array}$} & \multicolumn{2}{|c|}{$\begin{array}{c}75 \mathrm{~dB} \text { ver- } \\
\text { wysingspeil }\end{array}$} & \multicolumn{2}{|c|}{$\begin{array}{l}95 \mathrm{~dB} \text { ver- } \\
\text { wysingspeil }\end{array}$} \\
\hline $\begin{array}{l}\text { S rondom } \\
\bar{X}\end{array}$ & $\begin{array}{l}\text { Zwicker } \\
\text { Stevens }\end{array}$ & $\begin{array}{l}1,34 \\
1,95\end{array}$ & $\begin{array}{l}\text { Stevens } \\
\text { Zwicker }\end{array}$ & $\begin{array}{l}2,50 \\
2,66\end{array}$ & $\begin{array}{l}\text { PNdB } \\
\text { Stevens }\end{array}$ & $\begin{array}{l}2,10 \\
2,44\end{array}$ \\
\hline $\begin{array}{l}\text { Variansie rondom } \\
\mathrm{L}_{\mathrm{kr}} \text {-waardes }\end{array}$ & $\begin{array}{l}\text { Stevens } \\
\text { Zwicker }\end{array}$ & $\begin{array}{c}5,11 \\
12,58 \\
\end{array}$ & $\begin{array}{l}\text { Stevens } \\
\text { dB (D) }\end{array}$ & $\begin{array}{l}13,01 \\
18,37 \\
\end{array}$ & $\begin{array}{l}\text { Stevens } \\
\mathrm{dB}(\mathrm{D})\end{array}$ & $\begin{array}{c}5,97 \\
10,61 \\
\end{array}$ \\
\hline $\begin{array}{l}\mathrm{r} \text { tussen } \mathrm{C}_{\mathrm{jk}}{ }^{-} \\
\text {waardes en } \\
\text { Gelyke luidheid }\end{array}$ & $\begin{array}{l}\text { Zwicker } \\
\text { Stevens }\end{array}$ & $\begin{array}{l}0,988 * * \\
0,865 * *\end{array}$ & $\begin{array}{l}\text { Stevens } \\
\text { (ISO) } \\
\text { Stevens } \\
\text { (FAA) }\end{array}$ & $0,819^{*}$ & $\begin{array}{l}\text { PNdB } \\
\text { PNdB } \\
\text { (ISO) }\end{array}$ & $0,854^{*}$ \\
\hline
\end{tabular}

$* \mathrm{p}<, 01$

$* * \mathrm{p}<, 001$

\section{Die $75 \mathrm{~dB}$ verwysingspeil}

Die Stevens-metode is die mees konstante meting van luidheid op die $75 \mathrm{~dB}$ verwysingspeil $(2,50)(13,01)$. Hierbenewens toon die Stevens-metode met I.S.O.-korreksies die hoogste korrelasie $(\mathrm{r}=, 819, \mathrm{p}<, 01)$ tussen $\mathrm{C}_{\mathrm{jk}}$-waardes en gemiddelde gelyke luidheidswaardes van toetslinge. Hierdie metode, met moontlike aanpassings vir korreksies vir suiwerklanke, is dus die beste bepaling van menslike waarneming van luidheid op die $75 \mathrm{~dB}$ verwysingspeil.

\section{Die 95 dB verwysingspeil}

Aangesien die PNdB-metode die hoogste korrelasie $(\mathrm{r}=, 854, \mathrm{p}<, 01)$ toon tussen $\mathrm{C}_{\mathrm{jk}}{ }^{-}$ waardes en gemiddelde gelyke luidheidswaardes van toetslinge en ook die kleinste standaardafwyking $(2,10)$ rondom sy eie gemiddelde toon, kan aanvaar word dat die PNdBmetode die beste bepaling is van menslike waarneming van luidheid op die $95 \mathrm{~dB}$ verwysingspeil.

\section{Die $55 d B$ en $95 d B$ verwysingspeile gekombineerd}

Aangesien die Stevens-metode deurgaans oor alle verwysingspeile prominent na vore kom, kan in die algemeen aanvaar word dat die Stevens-metode tans die beste metode is waarvolgens 'n redelike konstante meting van luidheid oor 'n wye reeks van intensiteitspeile en frekwensies gedoen kan word. 


\section{Praktiese gevolgtrekking}

Vanuit 'n praktiese metingsoogpunt is dit duidelik dat van alle beswaringsnetwerke slegs die dB (D)-metode enigsins op die $75 \mathrm{~dB}$ en $95 \mathrm{~dB}$ verwysingspeile geregverdig kan word. Die dB (A)-metode vir die bepaling van luidheid, wat tans die mees algemene gebruikmetode van luidheidsbepalings is, lewer egter totaal onbevredigende resultate.

\section{GEVOLGTREKKINGS}

Finale gevolgtrekkings wat uit hierdie navorsingsprojek voortvloei, word ten opsigte van die spesifieke doelstellings van die ondersoek gemaak.

Die seleksie van 'n metode wat die waarneming van luidheid die beste weerspiël

(a) Geen bestaande meetmetode vir die waarneming van luidheid kan as hoogs akkurate maatstaf vir die waarneming van luidheid beskou word nie.

(b) Van die beskikbare meetmetodes is die Stevens-metode sonder enige korreksie die enigste metode wat oor ' $\mathrm{n}$ wye reeks van klankintensiteite en frekwensies 'n redelike akkurate weergawe van menslike waarneming van luidheid gee.

(c) Op die $55 \mathrm{~dB}$ verwysingspeil lewer die Zwicker-metode (Zwicker, 1965) die beste resultate.

(d) Op die 75 dB verwysingspeil lewer die Stenvens-metode (Stevens, 1961) die beste resultate.

(e) Op die 95 dB verwysingspeil lewer die PNdB-metode (Kryter, 1970) die beste resultate.

(f) Oor die algemeen bring die korreksies vir suiwertone van I.S.0., F.A.A. en Kryter geen verbetering by enige meetmetode mee nie. Alhoewel hierdie korreksiemetodes wel die meetmetodes verbeter op die $75 \mathrm{~dB}$ verwysingspeil ten opsigte van korrelasie tussen meetmetodes en gelyke luidheidswaardes van toetslinge, veroorsaak dit terselfdertyd dat meetmetodes minder konstant meet rondom eie gemiddeldes en berekende luidheid van verwysingsklanke.

(g) Die dB (A) -metode toon op elke verwysingspeil 'n onbeduidende verband met die waarneming van luidheid deur toetslinge. Hierdie bevinding het verreikende implikasies vir die praktiese meting van luidheid. Die dB (A)-metode is tans in algemene internasionale 
gebruik en kan op grond van die resultate in hierdie projek nie gebruik word vir die meting van luidheid nie.

\section{Die invloed van kulturele verskille op luidheidsnavorsing}

(a) Daar bestaan geen beduidende verskille tussen volkere ten opsigte van die waarneming van luidheid nie. Daar bestaan dus geen rede waarom navorsingsgegewens wat op nasionale grondslag versamel is, nie aanvaarbaar sal wees vir die doeleindes van die Internasionale Standaardisasie Organisasie nie. Twee kwalifikasies word egter vir hierdie gevolgtrekking gemaak: (i) Die gegewens waarop gevolgtrekkings baseer word, moet van 'n wye omvang wees. (ii) Die algemene beginsels van eksperimentele ontwerp moet in die beplanning van navorsing implementeer word.

\section{AANBEVELINGS VIR VERDERE NAVORSING}

Die gevolgtrekkings van die huidige ondersoek dui daarop dat die ideale meetmetode vir die waarneming van luidheid nog nie bestaan nie. Die gegewens wat vir die huidige ondersoek versamel is kan egter as grondige basis dien vir die ontwikkeling van sodanige meetmetode.

'n Studieprojek, deurgevoer deur 'n akoestiese ingenieur, sou die Stevens-metode vir die waarneming van luidheid verder kon verfyn om sodoende aan die eise van meting in hierdie studieveld te voldoen.

Daar bestaan tans ook nog geen meetinstrument wat volgens die Stevens-metode funksioneer nie. Die ontwikkeling van sodanige klankpeilmeter sal 'n belangrike bydrae tot die praktiese meting van luidheid wees.

Die vraag ontstaan of daar op die $95 \mathrm{~dB}$ verwysingspeil nog sprake van die betekenisvolle waarneming van luidheid kan wees. Hierdie intensiteitspeil is so hoog dat raserigheid en/of geraassteuring reeds 'n faktor kan wees wat 'n invloed uitoefen op die waarneming van luidheid. Om hierdie rede is dit dus nie verrassend dat die PNdB- en dB (D)metodes, wat spesifiek ontwikkel is vir die meting van vliegtuiggeraas, hier sterk op die voorgrond tree nie. Op hoë intensiteitspeile kan deur gebruik te maak van die gegewens van die huidige ondersoek verbeterings aangebring word aan die PNdB- en $\mathrm{dB}$ (D)-metodes om 'n meer betroubare meting van luidheid te gee.

Die gegewens van die huidige ondersoek is versamel deur 'n konstante verwysingsklank van $1000 \mathrm{~Hz}$. Toekomstige navorsing gebaseer op 'n $4000 \mathrm{~Hz}$ verwysings- 
klank sal ' $n$ verdere bydrae lewer tot die begrip van menslike waarneming van luidheid, veral omdat menslike gehoor meer sensitief is by $4000 \mathrm{~Hz}$ as by $1000 \mathrm{~Hz}$.

Die huidige ondersoek, wat die Stevens-metode van luidheidsbepaling as mees akkurate simulering van menslike gehoor uitwys, kan 'n belangrike bydrae lewer tot die meting van geraassteuringsinvloede in die industriële organisasie. Deur die Stevens-metode kan 'n meer akkurate aanduiding verkry word van die werklike invloed van geraas op produktiwiteit van werknemers. Die dB (A)-metode wat in die verlede toegepas is, word in hierdie studie ongeldig verklaar. Die Stevens-metode toon aan dat die mens meer sensitief vir klank is as wat tot dusver algemeen deur middel van die $\mathrm{dB}(\mathrm{A})$-metode aanvaar is. In die toekoms sal dus ook strenger beperkings neergelê moet word op die hoeveelheid geraasblootstelling van werknemer ten einde produktiwiteit te verhoog.

\section{OPSOMMING}

Mensike waarneming van luidheid word as basis van geraasmeetmetodes beskou. As gevolg van die verwarring en probleme wat by die gebruik van soveel as 18 internasionaal erkende meetmetodes vir geraas bestaan is 'n wêreldwye ondersoek organiseer waarin hierdie meetmetodes onder eenvormige toestande onderling vergelyk is. Die Stevens-metode word bevind die beste algemene simuleerder van menslike waarneming van luidheid te wees terwyl die Zwicker-metode op lae intensiteitspeile en die PNdB-metode op hoë intensiteitspeile goeie resultate lewer. Geen kulturele verskille tussen groepe toetslinge ten opsigte van luidheidswaarneming word identifiseer nie wat dus nasionale navorsing geprojekteer op internasionale standaarde wetenskaplik regverdig.

\section{VERWYSINGS}

Broadbent, D.E.; Little, E.A.J. Effects of noise reduction in a work situation. Occupational Psychology, 1960, 34, 133-140.

Cameron, P.; Robertson, D.; Zaks, J. Sound pollution, noise pollution, and health: Community parameters. Journal of Applied Psychology, 1972, Vol. 56 (1), 67 - 74.

Federal Aviation Agency. Sixth revised Draft of Proposed FAA Noise Certification Criteria, 1968.

I.S.0. Information about; I.S.0. Central Secretariat, Geneve, 1973.

Kryter, K.D. The Effects of Noise on Man. Academic Press, London, 1970.

Likert, R. A technique for measurement of attitudes. Archives of Psychology, 1932, 140.

Meij, G.V. A critical, historic survey of methods of measurement and assessment of annoyance caused by noise. The Transactions of the South African Institute of Electrical Engineers, September, 1971. 
Nunnaly, J .C. (Jr.) Introduction to Psychological Measurement. New York: McGraw-Hill, 1970.

Rozenberg, M.J. When dissonance fails: on eliminating evaluation apprehension from attitude measurement. Journal of Personality and Social Psychology, 1965, 1, 268-283.

Scheffé, H. A method for judging all contrasts in the analysis of variance. Biometrika, 1953.

Sidowski, J.B. Experimental Methods and Instrumentation in Psychology. New York, McGraw-Hill, 1966.

Stevens, S.S. Procedure for calculating loudness: Mark VI. Journal of the Acoustical Society of America, 1961, 33, 1577-1585.

Stricker, L.J. The true deceiver. Psychological Bulletin, 1967, 68, 13-20.

Van Wyk, A.J. Die Steuringseffek van Geraas op die Aandag van die Mens. Tesis, Stellenbosch, 1970.

Walters, A.A. Noise and prices. Oxford: Clarendon Press, 1975.

Zwicker, Von E.; Schart, B. A model of loudness summation. Psychological Review, 1965. 72, 3-26. 